IZA DP No. 8066

International Labor Mobility and Child Work in Developing Countries

Anna De Paoli

Mariapia Mendola

March 2014 


\title{
International Labor Mobility and Child Work in Developing Countries
}

\author{
Anna De Paoli \\ Università di Milano Bicocca \\ Mariapia Mendola \\ Università di Milano Bicocca, \\ LdA and IZA
}

\section{Discussion Paper No. 8066 \\ March 2014}

\author{
IZA \\ P.O. Box 7240 \\ 53072 Bonn \\ Germany \\ Phone: +49-228-3894-0 \\ Fax: +49-228-3894-180 \\ E-mail: iza@iza.org
}

Any opinions expressed here are those of the author(s) and not those of IZA. Research published in this series may include views on policy, but the institute itself takes no institutional policy positions. The IZA research network is committed to the IZA Guiding Principles of Research Integrity.

The Institute for the Study of Labor (IZA) in Bonn is a local and virtual international research center and a place of communication between science, politics and business. IZA is an independent nonprofit organization supported by Deutsche Post Foundation. The center is associated with the University of Bonn and offers a stimulating research environment through its international network, workshops and conferences, data service, project support, research visits and doctoral program. IZA engages in (i) original and internationally competitive research in all fields of labor economics, (ii) development of policy concepts, and (iii) dissemination of research results and concepts to the interested public.

IZA Discussion Papers often represent preliminary work and are circulated to encourage discussion. Citation of such a paper should account for its provisional character. A revised version may be available directly from the author. 


\section{ABSTRACT}

\section{International Labor Mobility and Child Work in Developing Countries}

This paper investigates the labor market effect of international migration on child work in countries of origin. We use an original cross-country survey dataset, which combines information on international migration with detailed individual-level data on child labor at age 5-14 in a wide range of developing countries. By exploiting both within- and cross-country variation and controlling for country fixed effects, we find a strong empirical regularity about the role of international mobility of workers in reducing child labor in disadvantaged households through changes in the local labor market.

JEL Classification: international migration, child labor, factor mobility, cross-country survey data

Keywords: $\quad$ F22, F1, J61

Corresponding author:

Mariapia Mendola

Department of Economics

Università di Milano Bicocca

Piazza dell'Ateneo Nuovo 1

20126 Milano

Italy

E-mail: mariapia.mendola@unimib.it

\footnotetext{
* We thank Frédéric Docquier, Marco Manacorda, Anna Maria Mayda, Michele Pellizzari and seminar participants at the 5th Migration and Development Conference in Paris, the 2012 CSAE Conference in Oxford, the 11th Journées LAGV in Marseille, DIW Berlin, Bocconi University and University of Florence for useful comments and suggestions. We are grateful to Juan Miguel Gallego for valuable inputs at an early stage of the project. Financial support from Centro Studi Luca d'Agliano (LdA) is gratefully acknowledged. Usual disclaimer applies.
} 


\section{Introduction}

International migration, mainly from poor to rich countries, has risen steadily over the last three decades and by the 2000s some developing regions have lost a substantial fraction of their population to emigration. Remarkably, the shares of labor force leaving many individual source countries is much higher than the proportionate changes in the labor force in many destination countries due to immigration. To cite a few examples, emigrants account for more than $10 \%$ of the population of Mexico or El Salvador, and as much as 20-30\% in smaller countries such as Albania, Jamaica or Trinidad and Tobago. The sheer scale of the cross-border movement of workers has recently raised much interest in its economic impact on the labor market in source countries. This is so as emigration changes a country's supply of labor and skill mix, and these effects may have significant consequences for a sending country's structure of wages. Indeed, there is a growing body of studies that document the positive impact of emigration on wages of non-migrating workers in the home country (e.g. Mishra, 2007 on Mexico; Borjas, 2008 on Puerto Rico; Bouton et al., 2011 on Moldova; Gagnon, 2011 on Honduras; Dustmann et al. 2012 on Poland). While the focus is mainly on the adult labor force, the improved labor maket conditions due to emigration may also affect child labor supply in migrant-sending regions (Edmonds 2008). This is so as child work is ultimately a parental decision driven by stark poverty such that higher parental wages may shift children's time allocation (Basu and Van, 1998). Yet, little evidence exists in the literature on the labor market effect of emigration on children in home developing regions.

This paper addresses this issue by empirically analysing the relationship between international labor outflows and child time allocation in a wide range of developing countries. We exploit both within- and cross-country variation in the emigration supply shock across heterogenous groups of workers in migrant-sending countries and our results are consistent with standard trade and labor-economics theory of migration.

According to the International Labor Organization (ILO) child labor is still a gigantic and persistent phenomenon in many developing countries. A global picture 
shows that in 2012 approximately 144.1 million children between 5 and 14 years were at work, 45 percent of whom are in Asia, 40 percent in Africa, and 6 percent in Latin America (ILO 2010). ${ }^{1}$ Several explanations of the phenomenon have been provided, including the influence of local labor markets, the need for extra household income to achieve minimum consumption, credit constraints combined with poverty and intra-household agency (see Edmonds, 2008 for a detailed and comprehensive review of the literature). More recently, some observers have highlighted the role of globalization and market integration in shaping child time allocation in developing countries through their impact on the labor market (Dinopoulos and Zhao, 2007; Edmonds and Pavcnik, 2005a and Epstein and Kahana, 2008). Yet, while there is some evidence of the little or no harm of international trade on child work in lowincome contries (Cigno et al, 2002; Edmonds and Pavcnik, 2006), the labor market impact of global migration flows on children in countries of origin has received less empirical attention.

According to the theory, the correlation between child labor and international emigration may be at work through changes in the local labor market which generate both income and substitution effects working in opposite directions. To the extent that labor migration outflows induce higher wages for adults, and leisure (non-work) is a normal good, children's labor market participation will fall (Basu and Van, 1998). On the other hand, if emigration is also associated to a rise in child wages, this will lead to an increase in children's labor supply (Cigno and Rosati, 2005, Manacorda and Rosati, 2010, Edmonds and Pavcnik 2005a). These competing effects, though, are likely to be differentiated according to the characteristics of the migrant labor force with respect to stayers, as well as to household- and individual-level attributes. Indeed, standard trade and labor-economics theories of factor markets, such as the Heckscher-Ohlin model and the factor-proportions-analysis model, predict that individual labor supply depends on the impact on factor prices of changes in relative factor supplies due to emigration (Borjas, 1995). In particular, assuming heterogenous labor and perfectly elastic capital, the labor market impact of emigration depends entirely

\footnotetext{
${ }^{1}$ ILO figures are based on a definition of child labor that includes any kind of activity with the exception of domestic work, as information on the latter is not available for many countries.
} 
on the relative skills of emigrants with respect to stayers (the concept is analogous to the one formalised in the context of immigration; see Borjas, 1999). Thus, since children typically compete in the low-skilled labor market, the substitution effect will be at work if emigration is relatively low-skilled with respect to non-migrant workers. At the same time, given that a child's labor supply decision is ultimately taken by the parent(s) in a unitary household framework, the improved labor market conditions faced by households endowed with unskilled labor can still raise family incomes in a way that tends to reduce child labor. It follows that the interaction between parental skill type and each country's relative skill endowment plays a key role in determining the income distribution effects of emigration on children.

We investigate this issue by generating an original dataset which combines information on the skill composition of migrants in each sending country with detailed individual- and household-level survey data on child labor (Docquier et al., 2007; MICS II-UNICEF, 2000). Hence, our analysis is based on a large cross-country survey dataset on more than 300,000 children aged 5-14 from 38 developing countries. The combination of detailed survey data on child labor with information on international migration outflows by skill allows us to test for interactive effects between parental skill level and emigration-induced changes in the local labor market. As the closest empirical counterpart of the latter, we use the skill composition of emigrant relative to non-migrating natives in the source country to directly measure the labor market competition effect induced by emigration (see Mayda 2006).

Overall, we find that children of low-educated parents are more likely to be at work. Yet, in countries with relative lower (higher) skill composition of emigrants, low-skilled resident parents are significantly less (more) likely to send their children to work. These results point to a significant role of international migration in shaping child time allocation in countries of origin through changes in the local labor market conditions. Our findings our robust to the use of an instrumental variable strategy based on a ten-years lagged emigration index. We also provide some evidence on the gendered consequences of the mobility of workers on child labor in migrant-sending countries. 
Our study sheds new light on the economic consequences of emigration for countries of origin, which have inspired an intense policy debate. In particular, we offer further insights on the distributional effects that emigration may have among current and future generations in low-income countries through the changes that conveys in the local labor market. Given the orientation of restrictive or selective migration policies in both source and destination countries, the way households respond in the local labor market to emigration supply shocks becomes increasingly important for policy makers. This is even more so if we consider that regulating child labor remains largely ineffective while being at work during childhood may have persistent negative effects on future individual well-being and country-level economic growth (Edmonds and Shrestha 2012; Beegle et al. 2009). As part of the globalization process, lifting barriers to international mobility of workers may address some of the economic roots of child labor in developing countries (Prichett 2006). The rest of the paper is organised as follows. Section 2 describes the theoretical background and related empirical evidence. Section 3 presents the data and descriptive statistcs while Section 4 describes the empirical strategy. Results are presented in Section 5 and Section 6 . Section 7 concludes.

\section{Theoretical and empirical background}

Standard theory on factors' mobility suggests that globalization and economic integration across national borders may have an impact on child labor mainly through changes in the local labor market, which lead to both a substitution and an income effect. In a simple Heckscher-Ohlin (HO) framework - where factors' price sensitivity to the relative abundance of factor endowments holds - if global market integration induces a drop in the supply of unskilled relative to skilled labor, unskilled workers in the country of origin will enjoy higher wages. The opposite is true for countries where emigrants are more skilled than stayers. ${ }^{2}$ In terms of child labor, this is to say that

\footnotetext{
${ }^{2}$ These predictions hold if the shock to the labor supply is substantial or if the country produces more goods than the number of primary factors of production. Indeed, in the HO model, the impact of migration on factors' rates of return depends on the extent of diversification of the origin country's production and on the size of the factor supply shock (Krugman and Obstfeld, 2006).
} 
emigration of low-skilled workers will increase unskilled wages and reduce the returns to education at origin, making it more likely for parents to send their children to work. At the same time, households endowed with unskilled labor also become better off, hence parents will be less likely to send children to work. The overall effect depends on which of the two channels dominates. A number of studies have addressed this empirical question by looking at the link between international trade flows and child labor in developing countries. They typically document a negative or no correlation between child labor and openness, which is mainly driven by the positive association between openness and income (see Edmonds and Pavcnik 2005a, 2005b, 2006; Cigno et al., 2002, among others). On the same theoretical ground though, there is a direct relationship between international mobility of workers and local labor market conditions, but little empirical evidence exists on the consenquences of the latter on child time allocation in migrant-sending regions.

The labor market impact of migration has been traditionally studied in the labor economics literature in the context of immigration. Similarly to the HO framework, also the well-established factor-proportion-analysis (FPA) model predicts that the distributional effects of immigration through wages crucially depend on changes in relative factor supplies due to migration, i.e. on the relative skills of immigrants to natives (Borjas, 1999). ${ }^{3}$ The same concept may be analogously applied to the case of emigration. If emigrants are relatively low skilled with respect to stayers, unskilled natives will 'gain' while skilled ones will 'loose', as their departure will induce an increase in the unskilled wage and a decrease in the skilled one. The opposite holds when migration is more skilled in relative terms. Overall, the key is the difference between the fractions of skilled workers in the migrating and non-migrating workforce. Hence, in terms of the distributional effects, the interaction between the individual factor type (i.e. skill level) and each country's relative factor endowments due to emigration (i.e. the labor-force skill composition) plays a crucial role in both the HO model and the FPA model.

\footnotetext{
${ }^{3}$ The difference between the HO model and the FPA model is in the labor demand curve. In both models, the latter is downward sloping. In the HO model, though, the labor demand curve is also characterized by flat regions, corresponding to the ranges of factors' endowments for which factor-price-insensitivity holds (Scheve and Slaughter, 2001).
} 
Estimating the labor market effect of emigration in countries of origin has increasingly attracted the attention of scholars, even though empirical evidence is often hampered by the paucity of data on labor market conditions in developing countries. ${ }^{4}$ The first contribution testing the labor-market impact of emigration using spatial variation and individual-level data is Mishra (2007). The latter study combines U.S. census data on the volume of Mexican emigration to the US with Mexican census data on individuals in the labor force to assesses the impact of the outflow of workers on Mexican wages. By using the supply shifts in skill groups induced by emigration, the author finds that a 10 percent increase in emigration, on average, increases wages in Mexico by almost 4 percent. Consistently with the latter piece of evidence, Aydemir and Borjas (2007) use individual data drawn from the Canadian, Mexican, and U.S. Censuses and show that a 10 percent change in labor supply is associated with a 3 to 4 percent change in wages in the opposite direction. In a study of Puerto Rican workers, Borjas (2008) finds that a 10 percent emigration-induced fall in the number of workers in a particular skill group raises the average wage by about 2 percent (see also Gagnon, 2011 and Elsner, 2013). In two recent papers Bouton et al. (2011) and Dustmann et al. (2012) use household level data to examine the impact of emigration on wages in Moldova and Poland respectively, two countries where emigration of the labor force is significant. Results show that emigration flows yield a positive and significant impact on wages at origin, and the magnitude of the effect is also close to the one estimated by Mishra (2007). ${ }^{5}$

\footnotetext{
${ }^{4}$ The vast majority of research has focused on the impact of labor inflows on the destination country, in particular on the US wage structure (Borjas, 1999a; Borjas, 2003; Card, 2005). One common identification strategy used in this literature makes use of variation in the immigrant share across labor market units defined on the basis of both geography and skills. The latter are measured by the level of education, by the interaction between labor market experience and education, and, when available, by the individual occupation (e.g., Card, 2001; 2005; Borjas, 2003 among others). The same strategy has been used by recent studies on the labor market impact of emigration on non-migrant natives in the source country.

${ }^{5}$ Using different approaches and focusing more on geographic (or sector) averages rather than individuals, other contributions have shed light on the labor market impact of emigration in countries of origin. In a seminal empirical paper, Lucas (1987) uses annual time series data from 1946 to 1978 on sectoral wage and employment to show that mine worker emigration to South Africa has raised agricultural wages in Malawi and Mozambique (see also Lucas, 2005). Robertson (2000), Chiquiar (2008), and Hanson (2004) provide evidence that those Mexican states that have greater international trade and migration links have enjoyed faster growth in average income and labor earnings. In yet another study, Hanson (2006) suggests that average hourly earnings in states with high emigration rates increased by 6 to 9 percent, compared to states with low emigration rates.
} 
Overall, the above evidence, while covering a good range of migrant-sending countries, is consistent in showing that non-migrating workers at origin enjoy higher wages due to a drop in the local labor supply due to emigration, and the distributional effects of the latter depend on the emigrants' skill composition. In order to provide a global picture of such a relationship, in Figure 1 we plot relative wages between unskilled and skilled workers (i.e. the relative unskilled wage) against the relative skill composition of emigrants to stayers (RSC index) for the largest set of countries worldwide on which homogeneous data are available (Docquier et al., 2007; Oostendorp, 2012). ${ }^{6}$ From the definition of RSC, the higher is the latter index, the more unskilled are emigrants with respect to stayers (see next section). The combination of cross-country data on relative wages and emigration in 2000 allows us to plot the link between the two variables for a set of 91 countries. The picture suggests a positive correlation, namely the higher is the fraction of low-skilled emigrants relative to the non-migrant labor force, the higher are relative unskilled wages in the country of origin. This is consistent with both theoretical predictions and empirical evidence described above.

-Figure 1 about here-

According to the theory, changes in wages induced by the fall in local labor supply may affect child time allocation in migrant-sending regions. Dinopoulos and Zhao (2007) use a general equilibrium-model to show that emigration of unskilled (skilled) workers increases (reduces) the incidence of child labor via a labor substitution effect. On the contrary, Epstein and Kahana (2008) argue that temporary emigration

\footnotetext{
${ }^{6}$ The data source of the RSC index is Docquier et al. (2007), which we further use in our inferential analysis below. Both the dataset and the RSC index are explained in details in Section 3 in the paper. Data on wages are based on Oostendorp (2012) which is, to the best of our knowledge, the most comprehensive database on earnings worldwide by occupation (OWW http://www.nber.org/oww/). The database contains occupational wage data for 161 occupations in 171 countries from 1983 to 2008. The occupational wage data are derived from the ILO October Inquiry database (http://laborsta.ilo.org) by calibrating the data into a normalized wage rate for each occupation classified as ISCO88. We use a measure of relative wages of unskilled workers by classifying as unskilled those occupations that belong to the 9th ISCO category, which includes 'elementary occupations'. Most occupations in this group require primary education, which is exactly the same educational level we use to define unskilled migrants (and stayers) in our analysis. So, in a nutshell, unskilled wages are earned in those occupations that require no more than primary education. We then construct, for each country, the relative wage as the ratio of (average) wages in unskilled occupations over (average) wages in skilled occupations.
} 
of unskilled workers might help households overcoming a minimal survival income threshold that would lead to a reduction in the incidence of child labor. Taking into account both the cost of the family's temporary separation and the benefit of receving remittances, the household income effect would reduce labor supply, increase wages and allow both migrant- and non-migrant-households to take their children out of the labor force.

In the most general household-economics model of child labor, parents care about their own and their children's consumption and decide to send their children to work whenever they cannot afford to consume 'leisure' or non-work (Basu and Van, 1998). ${ }^{7}$ This is to say that household low-income or poverty is a key determinant of child labor as it influences the family's valuation of child time (see also Edmonds, 2007). Thus, as long as labor out-migration determines a change in the wage rate, it is possible for parents to shift their children's time allocation. ${ }^{8}$ In terms of distributional effects on children, then, what is crucial is the interaction between parental skill type and each country's relative skill endowment due to emigration. In particular, recalling that children are imperfect substitutes for adult unskilled labor, if emigrant workers are relatively less (more) skilled with respect to stayers, children of low-skilled parents may either work more (less) due to higher (lower) low-skilled wages, or work less (more) because of a positive (negative) household income effect.

Evidence on the impact of emigration on child labor through changes in the local labor market in scant. ${ }^{9}$ Much of the literature on the effects of international migra-

\footnotetext{
${ }^{7}$ There is a large consensus in the child labor literature that the alternative to children's work is not necessarily schooling. There is a return to leisure that parents may value and could be important for the child's future welfare. Thus, the marginal utility of time will depend on how the family values the contribution of play to child welfare and how time spent in (both market and home) production affects the standards of living. Moreover, there are reasons to child labor beyond its implications for schooling, because of the several (short-term and long-term) negative consequences of child work (Edmonds, 2008a; Beegle et al. 2009).

${ }^{8}$ In their seminal theoretical model, Basu and Van (1998) point out that in a unitary household framework, children and adults are substitutes in production (the 'substitution axiom'), and children only work when parental income is below subsistence levels (the 'luxury axiom'). With the combination of the above axioms, the authors show that a total ban to child labor would lead to a rise in the wages of adults in response to the excess of labor demand. But as adult wages rise, the parents will not want to send their children to work anymore, making the ban redundant due to the labor-market effect.

${ }^{9}$ One of the earliest and strongest evidence of the link between adult market wages and child labor supply comes from the U.S hystory. Goldin (1979) uses census data from the late ninetheencentury Philadephia to show that higher father's wages increase (male and female) child labor supply, concluding that there is a strong complementarity between parental (father's) labor market condi-
} 
tion on children has focused on investment in child education through human capital externalities. For a cross-section of countries, Beine et al. (2008) report a positive correlation between skilled emigration to rich countries and the increase in the stock of human capital, due to higher incentives to acquire education. ${ }^{10}$ Little is known though on the direct effect of emigration-induced labor market changes on children in developing countries. Most of the empirical literature has focused on the impact of (adult) family members' emigration on children's time allocation (i.e. labor but more frequently schooling) at the household level. The mechanism through which the latter link may be at work is mainly an increase in household income through remittances, along with intra-household time allocation patterns. Yang (2008), for instance, find that in the Philippines receiving remittances from migrants abroad reduce labor supply of household's children aged 10-17. Similarly, Mansuri (2006) on Pakistan finds that children in origin households are less likely to be involved in economic work and report working for substantially fewer hours. Our study complements these findings. Even though the income gains to migrants' family members through remittances are only imperfectly correlated with the labor-market consequences of labor outflows on non-migrating workers in the sending country, in our analysis we do consider both a proxy for emigration exposure at the household level and an aggregate measure of remittances received by the migrant-sending country (Hanson, 2008).

\section{The data}

Our empirical analysis is based on a cross-country household survey dataset coupled with country-level information on international migration from a large set of developing countries. The former is the Multiple Indicator Cluster Survey at the end-decade assessment (MICSII), an international household survey initiative led by UNICEF tions and children's work. Similar findings are reported by Rosenzweig and Evenson (1977), using aggregate data from rural India in the 1960s (see also Skoufias, 1993; Levy, 1985). Overall, there is a limited but consistent amount of evidence on the effect of increases in local labor demand on children's time allocation and labor supply in developing countries (Manacorda and Rosati, 2010; Parikh and Sadoulet, 2005).

${ }^{10}$ The migration impact on human capital formation and schooling may also be at work through an increase in household income via remittances - see, for example, Cox Edwards and Ureta (2003), Lopez Cordoba (2004), Yang (2004) for analyses at the household level. 
that provides internationally comparable micro-level information on child labor and schooling for 38 developing countries (22 of which are in Africa, 8 in Asia, 5 in Latin America, 3 in Eastern Europe). Most of the MICS II were implemented in 2000 and contain several household level information, such as demographic characteristics, family composition, wealth indicators and education information on household's members. ${ }^{11}$ The most important advantage of this dataset is that it contains homogeneous data on both the incidence and intensity of different types of work supplied by children between 5 and 14 years of age. ${ }^{12}$ Studying child labor during the latter time span is particularly important as the first few years of a child's life are formative and play a vital role for future socio-economic well-being (Emerson and Portela Souza, 2011, Beegle et a. 2011). Moreover, data on child labor activities include market work, family business and general domestic work. ${ }^{13}$ This is also a plus as most children work at home or with their family rather than in the formal market but any kind of job trades off with other activities that are good for child development (i.e. play or schooling) (Edmonds, 2008b). Schooling data is also collected in a consistent manner across countries in the MICSII survey by including information on children's school attendance during the current school year. ${ }^{14}$

For each of the 38 countries included in our analysis, we measure both the extensive and the intensive margin of child labor. As for the former we know the number of hours children work in each activity separately (i.e. market work, family business and chores) during the last week. We also use a more synthetic variable that corresponds to the total number of hours worked by the child over the different activities. As for the intensive margin, we define child labor dummies as whether the child work for more than 28 hours per week in both any and each of the above activities respectively.

\footnotetext{
${ }^{11}$ The UNICEF-MICS surveys in Congo and Angola were administered in 2001.

${ }^{12}$ Questions are directed towards the mother or caretaker of all children aged 5 through 14 . Interviews are confidential and no compensation is provided to respondents. One important advantage of the MICS dataset is that the time allocation module is nearly uniform across countries. Of course, even though the original questionnaires were largely identical, local understanding of the questions can differ.

${ }^{13}$ According to the survey questionnaire, domestic chores include fetching wood or water, caring for children, cooking, shopping, cleaning, whashing clothes, etc.

${ }^{14}$ Such a variable, though, is unable to capture children's time inputs into school (e.g. school attendance is not constant during academic years and subject to seasonality) and educational achievements.
} 
This is based on two main reasons. First, as mentioned above, children are typically engaged in multiple activities but all of them may have the same marginal cost in terms of forgone human capital. Thus, when studying the multiple potential uses of child time it is important to consider as broad a definition of child work as possible (Edmonds, 2008a and 2008b). Secondly, while it is difficult to find an agreed measurement standard of child labor in the literature (e.g. 14 hours per week, 40 hours per week), we employ a common time threshold of 28 hours per week. Importantly, the latter is consistent with the evidence based on the same MICS dataset that the probability of school attendance significantly decline when children work for more than 29 hour a week (Edmonds, 2008b). ${ }^{15}$

The data source for international migration is the database produced by Docquier et al. (2007), which contains estimates of emigration stocks and rates of the working-age population (aged 25 or more) from 195 source countries to OECD countries in 1990 and 2000. The main feature of this dataset is the disaggregation of migration stocks by country of origin and skill (i.e. educational attainment). Three levels of schooling are characterised: low-skill workers are those with primary education (0 to 8 years of schooling completed), medium skilled workers are those with secondary education (9 to 12 years of schooling) and high-skilled workers are those with tertiary education (13 years and above). Key in our study is having a direct indicator of the skill composition of emigrants relative to stayers in order to measure the emigration-induced labor market competition effect as predicted by the factor-endowments models. Constructing such a direct measure requires information on emigrants and their skill level and, in comparable terms, the same statistics are needed on the non-migrating population. By containing such information, the Docquier et al. (2007) dataset allows us to contruct the RSC index $\left(\frac{m_{j}^{\text {low }}}{1-m_{j}^{l o w}} / \frac{l f_{j}^{\text {low }}}{1-l f_{j}^{l o w}}\right)$, that is the ratio of low-skilled to skilled labor in the migrant relative to the stayer populations in country $j$ (see Mayda, 2006). The higher is the latter index, the lower is the skill composition of emigrants with respect to stayers. The advantage of the RSC index is that it considers the skill composition of emigrants (i.e. the number

\footnotetext{
${ }^{15}$ We also used a more inclusive indicator of child labor participation in any work as dependent variable and results go in the same direction as the ones shown (available upon request).
} 
of low-skilled emigrants over the skilled ones) as well as the resident labor force skill composition (in particular it measures the former relative to the latter) and therefore it is a proxy for changes in the relative wages induced by migration.

Combining the above sources of micro and macro-level information, we assembled an original data set for 38 less developed countries where both child labor and outmigration are relevant phenomena. In this way we include in the analysis more than 300,000 children aged 5-14. We further use country-level information on remittance inflows in 2000, drawn from the World Bank's estimate based on the International Monetary Fund's Balance of Payments Statistics Yearbook 2008. Yet, information on remittances are only available for 28 countries among those for which we have individual level information.

For the full set of countries included in our analysis, Table 1 reports the incidence of child labor (according to the definition of the extensive margin described above), total emigration rates as a proportion of the total labor force born in the sending country (including migrants themselves), the RSC index that measures the share of unskilled migrants as a proportion of the share of the unskilled labor force and finally the level of remittances as a percentage of the country GDP. Column 1 shows that the share of children involved in any work activities for more than 28 hours per week (either on the market or at home) is quantitatively important in all of the countries considered and variability spans from a minimum of $1.5 \%$ to $52.7 \%$. On average the migrant population is around 5\%, even if for some countries it is greater than $20 \%$ (column 2). The RSC index shows that in all of the countries out-migration is more skilled than the resident labor force. Yet, there is great variation in this measure as for some countries either the share of unskilled migrant population is relatively high or the share of unskilled labor force is relatively low. Column 5 reports remittance rates as percentage of the GDP and it is worth noting that for Albania, Moldova and Lesotho remittances in 2000 are a substantial source of income, reaching respectively 16, 14 and 34 percentage of the GDP.

-Table 1 about here-

Based on survey data, Table 2 reports descriptive statistics of main characteris- 
tics of children and their families. On average, children with low-educated household head, relatively older kids, those living in rural areas and having larger family size work more frequently, while those who live with their own mother work less. Moreover, the share of working children is higher at the lower quantiles of the wealth distribution, where the latter measures households' socio-economic status based on individual/household assets ownership. ${ }^{16} 21 \%$ of the children sample are employed in some work activities, where domestic work is prevalent $(7 \%)$, followed by market work $(6 \%)$ and family business $(5 \%)$. It should also be noted that school attendance is relatively high, as $77 \%$ of the children are attending school during the current shool year. The different work activities and school attendance are not mutually exclusive though, with $15 \%$ of children engaged in both.

-Table 2 about here-

In Figure 2 we report the scatter plot of the correlation between our main variables of interest at the origin-country level, i.e. the average incidence of child labor, and the RSC index. The correlation is negative suggesting that the higher is the unskilled composition of emigrants relative to stayers, the lower is the share of children involved in work activities. This is consistent with expectations but, as mentioned in the former section, such a relationship is likely to be heterogeneous across group of workers of different type (i.e. with different skill levels) because of the distributional effects of emigration-induced changes in the local labor market. This is what we are going to test in what follows.

-Figure 2 about here-

\section{Empirical Strategy}

We start by estimating a child labor equation in order to investigate the individuallevel determinants of children's labor supply within countries with different emigra-

\footnotetext{
${ }^{16}$ The wealth index is included in the MICS survey and is based on the possession of consumer durables and housing characteristics (i.e. house amenities such as material of dwelling floor, water and sanitation, crowding household characteristics). Such an asset-based wealth index is a widely used instrument for measuring the economic situation of households in developing countries.
} 
tion flows. The empirical model is a linear specification as follows:

$$
Y_{i j}=\alpha_{0}+\alpha_{1} X_{i j}^{\prime}+\alpha_{2} H_{i j}+u_{j}+\varepsilon_{i j}
$$

where $Y_{i j}$ is a child labor variable indicating whether child $i$ in country $j$ is at work. We first use a generic child labor variable which takes into account any type of work. We then distinguish between each type of activity, i.e. market, family business and domestic work, using both extensive and intensive margin indicators of child labor. As for the former, we use a dummy variable equal to one if the child works for more than 28 hours per week (in both any and each type of activity). As for the intensive margin, we use hours of work (both total and in each specific activity) as a continuous dependent variable. In a last specification, we test a school enrollment equation by using whether the child attended school in the current survey year as dependent variable, even though the latter does not exclude labor supply. ${ }^{17} X_{i j}$ is a vector of individual and household-level characteristics typically shaping child labor, including age, gender of both the child and the household head, controls for father's and mother's status (absent, dead or in the household), family size, number of children aged 0-4, a dummy for urban area and the wealth index in quintiles (summary statistics for these variables are reported in Table 2). ${ }^{18}$ We further include controls for child's age-specific country-level international and internal legislation on child labor and compulsory schooling in 2000. Indeed, laws which set the children's

\footnotetext{
${ }^{17}$ The test on child schooling is intended as a robustness check of our child labor estimates. This is because, first, child labor and schooling are not mutually exclusive at the level of the child (in our sample and in general in developing countries). Secondly, indicators of school attendance do not measure children's time inputs into school nor school achievements, which would be a better proxy for children's human capital investment, as opposed to children's time use into labor. Moreover, the variable of child school attendance in the current school year presents a high number of missing observations with respect of our child labor estimation sample (one third of observations are missing). Yet, we still use the latter variable as, among other variables in the MICS survey, the latter is the most homogenous across all countries in our sample and its time reference is the most contemporaneous with respect to our key regressor of interest. Overall, a throughout analysis of the link between emigration and child schooling would require higher quality data on the latter variable.

${ }^{18}$ We further include two dummy variables for missing information on rural/urban household residence and the wealth index. This is so as in surveys for Trinidad and Tobago and Venezuela, information on whether the household is located in a urban/rural area is missing (this corresponds to less than $2 \%$ of the whole sample). Similarly in Bosnia and Herzegovina and Uzbekistan information on household wealth is missing ( $5 \%$ of the sample). Thus, we include two dummies for these missing information in these four countries as to retain the latter countries in our sample (even though excluding those countries from the analysis does not change the results).
} 
minimum age to work or to leave school may potentially prevent child labor if enforced successfully (Edmonds and Shrestha 2012). The ILO Minimum Age Convention, 1973 (No.138) and the ILO Worst Forms of Child Labour Convention, 1999 (No. 182), for example, were ratified by each country in different years, not all prior to 2000 though (e.g., Albania in 1998, Angola in 2001). ${ }^{19}$ Thus, we include two dummies equal to one if the child lives in a country where in 2000 child labor at his/her age is banned by either international or internal regulation. ${ }^{20}$ Similarly, we control for a dummy variable equal to one if the child's age falls below compulsory schooling minimum-leaving-age in 2000, and zero otherwise. ${ }^{21}$

Among individual level characteristics, $H_{i j}$ is a key variable that measures the skill level of child $i$ 's household head, characterized by her/his educational achievement. ${ }^{22}$ $H_{i j}$ is a dummy variable equal to one if the household head is low-skilled, i.e. has no more than primary education ( $v s$ secondary, tertiary and other levels). The latter follows the same classification of educational attainment as reported in the countrylevel migration dataset. $u_{j}$ are country fixed effects which control for any observable and unobservable average country factors affecting child labor such as the level of development of the country (e.g. GDP), the aggregate level of remittances to the country, and the institutional context. $\varepsilon_{i j}$ is the error term. Our child labor estimates always allow for spatial correlation so that standard errors are clustered at the country level.

Yet, as outlined in former sections, the effect of parental skill on child labor may be heterogenous across economies with different out-migration flows via a labor market effect. In order to test this hyphothesis, we take advantage of the panel data structure of our combined dataset (children within country) and exploit the

\footnotetext{
${ }^{19}$ While child work is prohibited by both conventions for children younger than 15 , some forms of light work are allowed in some countries (e.g. in Dominican Republic light work is allowed after 12 years of age).

${ }^{20}$ Information on country-specific internal legislation and its timing is based on Edmonds and Shrestha (2012).

${ }^{21}$ Data on schooling minimum-leaving-age, compulsory school duration and starting age for each country since 1998 are from UNESCO (see also Edmonds and Shrestha, 2012).

${ }^{22}$ Information on the educational level of the household head is missing for $7 \%$ of our children sample. When possible, we impute the missing values using the educational level of the 'woman in charge', i.e. the primary care taker of the child according to the survey questionnaire. This was possible for $2 \%$ of children in the sample, while the remaining $5 \%$ missing observations are dropped.
} 
cross-country variation in the emigration supply shock across groups of household heads (i.e. children's parents) with different skills (as captured by education) in the migrant-sending country. Hence, we estimate the child labor equations with country fixed effects and test for interactive effects between parental low-education and country-level migration covariates. The model is as follows:

$$
Y_{i j}=\alpha_{0}+\alpha_{1} X_{i j}^{\prime}+\alpha_{2} H_{i j}+\alpha_{3} H_{i j} * m_{j}+u_{j}+\varepsilon_{i j}
$$

where $m_{j}$ is a measure of the emigration supply shock in country $j$. Given the focus of our analysis, we use the RSC index as a measure of $m_{j}$, that is the skill composition of emigrant relative to resident workers in the home country (see details in the former section). ${ }^{23}$ Thus our coefficient of interest is $\alpha_{3}$, i.e. the interactive effect between the child's parental skill and the country-level measure of the emigrationinduced pressure on the local labor market. As predicted by the theory, the latter parameter indentifies the distributional effects of emigration on children through differencecs in the local labor market conditions. The direct effect of the RSC index is perfectly absorbed by the country fixed effects which control for all unobserved cross-country heterogeneity. ${ }^{24}$

Yet, emigration-induced income gains may also come from migrant's remittances which may have a direct effect on child labor over and above chages in the local wage rates. In order to control for that, in a set of robustness checks we further amend our regression specifications by including the interaction term between the level of remittance inflows (as a percentage of the GDP) and the individual (parental) skill level (the direct effect of remittances on child labor is always controlled for by the country fixed effects). ${ }^{25}$

\footnotetext{
${ }^{23}$ In a set of reduced form specifications, we also test for the interactive effect of different measures of workers' out-flows such as the emigration rate over the total population, or the unskilled emigration rate over the total unskilled population. All results are consistent with the ones presented below and they are available upon request from authors.

${ }^{24}$ A similar empirical strategy has been used by Mayda (2006) in her cross-country study on public opinion and immigration. In the latter paper the significance of the interactive effect between the individual skill and country-level RSC of immigrants relative to natives is put under test in order to investigate the role of labor market changes on global attitudes towards immigration.

${ }^{25}$ This is a robustness check as the emigration-induced change in the skill mix of the local labor force, and thereby in the relative wage, is only imperfectly correlated with the income gains to migrants' family members coming from remittances (note, for instance, that the RSC index also
} 
In the benchmark model emigration is treated as exogenous. Indeed, the RSC index is based on emigrant stocks which are the most exogenous measure of labor mobility as they reflect the cumulative flows of permanent and temporary workers over the past decades up to 2000 (Docquier et al., 2007). This is to say that most relevant determinants of emigration are likely to reflect economic and other conditions prevalent much before 2000, which reduces endogeneity and simultaneity bias in our model specification. More importantly, we investigate interacted effects in different sub-groups of the population, while controlling for unobserved heterogeneity through country-fixed effects. The latter strategy helps confirming identification since any potential country-level omitted variables would have to behave differently across subgroups in order to exhibit the sorts of heterogenous effects we find. Yet, in order to reduce simultaneity and endogeneity concerns we further use the ten-years lagged RSC of emigrant with respect to resident workers based on data on the stocks of migrants in 1990 (Docquier et al., 2007).

\section{Results}

We start by reporting individual level determinants of children's labor supply. Results in Table 3 show the expected sign. In particular, children whose household head is relatively low skilled (i.e. has no more than primary education) are significantly more likely to supply labor of any kind (market, family business work, chores) and less likely to attend school. Household head's education is a typical proxy for earnings as low-skilled adults are likely to face worse labor market conditions which are strongly associated with child labor in our cross-country sample of children. Moreover, older children are more likely to be at work and male children are more frequently employed in market work, while females are significantly more engaged in domestic chores. Male headed households, on the other hand, are significantly more likely to send children to work.

depends on the resident labor force skill composition). Thus, if the latter variables are indipendent, leaving (the interacted effect of) remittances in the error term should not generate any estimation bias. 
-Table 3 about here-

Overall, it seems that more disadvantaged households are more likely to dispatch their children to work. This is so as, on average, children living in rural (urban) areas are positively (negatively) associated with labor supply of any kind. Moreover, the lower the level of wealth of the child's family, the higher is the probability of child labor. Family size is related to a moderate decrease in hours worked, especially in domestic chores. The number of siblings under 5 years old is positively associated with the probability to work and negatively associated with school attendance.

Finally, our regression specifications always control for the presence of either the mother or the father in the family. In particular we include two sets of dummies for whether either the mother or the father is dead, and whether either the mother or the father is away from home. Results show that if the mother lives at home, the child probability to supply domestic work significantly decreases while school attendance significantly increases. Fathers' presence instead seems to play little or a positive role in favouring schooling and child family business work. These findings are consistent with 'traditional' gender roles within the family with respect to investment in children, even though we cannot explore further this aspect in this context. What is important to us, though, is that the dummy variables for whether the mother or the father is present at home allows us to have a control proxy for whether there is a case of maternal or paternal emigration in the household.

The variables controlling for both international and national minimum-age regulation of child labor and schooling do not influence significantly child labor. On the other hand, children in compulsory school age are more likely to be attending school. These results are consistent with findings reported by Edmonds and Shrestha (2012) which uses the MICS international dataset to carefully explore the effect of the same legislations and compulsory schooling laws on child labor.

In the individual model above, we constrain the coefficient on parental skill to be the same for all countries in our sample. Yet, according to the theory discussed earlier, the effect of parental skill on child labor may take place in the labor market and may change according to different levels of labor outflows and skill mix. Thus, 
we take advantage of the panel structure of our data (children within country) and investigate whether the skill level effect is heterogenous across countries with different emigration supply shocks. In particular, we estimate equation (2) above while focusing on the interactive effect between between parental low-skill level (as measured by household head's primary education) and the relative skill compostion of emigrant to non-migrant workers (RSC index). It is worth recalling that according to our RSC characterization, the higher is the index the lower is the skill composition of emigrants with respect to the resident labor force. Here the RCS index is the log of 1 plus the skill composition of emigrants relative to stayers.

Results are presented in Table 4 where we report estimates of the main regressors, while individual level covariates remain stable and robust. Results show that having a low-educated household head has a significant and positive (negative) effect on the child's probability to work (to attend school). Yet, in countries with a lower skill composition of emigrants relative to the resident labor force, low-skilled parents are significantly more likely to withdraw their children from work in any activity, i.e. market, family business and chores. The low-skilled emigration supply shock is also associated with a decrease in the amount of working hours of children in low-skilled households. Ceteris paribus, a 10 percent increase in low-skilled emigrants relative to resident workers generates a reduction by 0.6 percentage points (p.p.) in the probability of chidren in low-skilled households to work in any activity for more than 28 hours per week, and a reduction in the total number of hours of work by more than 4. The pattern of child labor reduction associated with the RSC index considering specific types of work is similar being equal to 0.4 p.p. for market work, 0.3 p.p. for family business and chores. Weekly hours vary correspondingly, i.e. they decrease by $2.7,1.9$ and 1.3 respectively. At the same time, a 10 percent increase in RSC is associated with a higher probability of children's school attendance in low-skilled households by 0.8 p.p. Overall, by showing a negative association with child labor in low-skilled families, emigration of relatively low-skilled workers turns out to mitigate or offset the positive direct effect of parental low-education on child labor. 
In Table 5 we check the robustness of our results to the inclusion of the interacted remittance variable (the direct effect of remittances is always control for by country fixed effects), the availability of which reduces our sample by ten countries. ${ }^{26}$ Thus, in the odd columns we report RSC estimates by using the same reduced sample of 28 countries and results are qualitatively similar to those discussed above with the largest sample. On the other hand, the interacted RSC effect is robust to the inclusion of the interacted remittance effect at the country level (even columns). In particular, in countries with relative lower skill composition of emigrants, low-skilled resident parents are still significantly less likely to send their children to work in each activity, i.e. market, family business or domestic work. Point estimates are very similar to the ones presented above albeit slighlty less precisely estimated. The latter difference in estimated cofficients, then, is mostly due to the decrease in the sample size (i.e. a decrease in the cross-country variation of our migration index due to a drop of ten countries) rather than to the role played by remittances.

-Table 4-5 about here-

We interpret these results as evidence that emigration may affect child labor in contries of origin through a labor market competition effect. This is so as RSC is a direct measure of the pressure on the local labor market induced by the emigration of working-age adults, thereby being a proxy for differences in relative wages (see Mayda, 2006). Accordingly, where the skill composition of emigrant relative to resident labor force is lower, the labor market competition of unskilled local workers decreases pushing their wages up. Thus, our results suggest that children will benefit from this income effect by decreasing their likelihood and intensity to work. On the other hand, a relative lower skill composition of emigrants with respect to stayers is positively associated with the probability of children to be attending school. This confirms that better labor market conditions of parents induced by emigration of adult workers result in an improvement in children's status and time allocation within the family.

\footnotetext{
${ }^{26}$ For the seek of space, we only report linear results of the child probability to work. Results on hours of work are available from authors upon request.
} 


\subsection{Addressing identification issues}

A concern related to the robustess of our results is that we have assumed that the RSC index is exogenous to child labor decisions. Indeed, some omitted variables may simultaneously affect the relative skill composition of emigrants and child labor in a way that tend to bias our results. Yet, as mentioned above, there are two reasons why simultaneity may be less of a concern. First, our RSC index is based on stocks of emigrants in the 2000 which are the result of predetermined variables at work earlier than 2000, and thereby less likely to be simultaneous with respect to child labor outcomes. Secondly, we focus on interaction effects and our estimates always control for unobserved cross-country heterogeneity by including country fixed effects. Hence, it is difficult to think of country-level unobservables that behave differently for skilled and unskilled household heads in each country as to exhibit the heterogenous results that we find. ${ }^{27}$

Nevertheless, in order to further dissipate concerns about simultaneity bias, in what follows we estimate the same child labor equation as above while using a lagged (10 years before) stock-based emigration variable as an instrument for the $2000 \mathrm{em}$ igration variable. From the same migration database (Docquier et al., 2007) we construct the 1990 RSC index, which is a predetermined variable highly correlated with RSC in 2000 but unlikely to be related to current child labor. This is to say that shocks to the unskilled migration ratio in 1990 do not impact child labor decisions in 2000 within unskilled families. Reverse causation issues are also attenuated as our sample of children is in the age-range 5-14 and by using a 10-years lag most of our sampled children we not even born. Thus, as long as we control for country fixed effects, the ten-year lagged RSC is orthogonal to child labor in 2000 and may affect

\footnotetext{
${ }^{27}$ We further checked the robustness of our results by running a set of more demanding specifications. In a first specification we exploit variation across countries within a child cohort by including country-cohort fixed effects (i.e. the interaction between child age and country dummies) along with standard country fixed effects. This is meant to wipe out cyclicality effects which are country-age specific. In a second robustness check we specify a child labor model where we include standard country and wealth-quintiles fixed effects along with the interaction of the two. This specification indicates that we are identifying the coefficient of interest from variations in child labor and emigration that occur within a country/wealth quintile cell. In this way we are able to control for any factor that is both country-specific and correlated with the household wealth status (e.g. country-specific levels of poverty). In both cases findings are not siginifcantly different from the ones presented in the text (results are availble upon request).
} 
the latter on through subsequent emigration.

Results are reported in Table 6. In Panel A we estimate a reduced form equation, in which we regress the child labor outcomes against the lagged low-skilled emigration composition. Overall, findings are consistent with those reported in the previous section and show that the (lagged) low-skilled emigration composition is negatively associated with current child labor in all categories, i.e. market. family business and chores, and positively correlated with school attendance. The magnitude of the effect is smaller as the lag between the labor emigration supply shock and children's time allocation is quite large. In Panel B of Table 6 we report the two stages-leastsquare estimation results. First stage estimates show a strongly significant correlation between the lagged (interacted) migration rate and the current (interacted) RSC index (col. 1). According to the F-test for the significance of the instrument, the lagged RSC is not weakly correlated with the potential endogenous variable (Stock and Yogo, 2002). The second stage results, where the key explanatory variable is instrumented, are qualitatively similar to those in the baseline specification (col. 210). This is due to the fact that the lagged migration rate is a powerful proxy for current migration rate, as the serial correlation in emigration is strongly persistent. In terms of magnitude, the slightly higher coefficients of IV results with respect to OLS may suggest that countries where low skilled emigration showed the highest persistance are those where children work less (in unskilled families).

Findings are robust and consistent in showing that the consequences of emigration on child labor may be at work through changes in the labor market, and that the effect of low-skilled emigration may be positive in terms of child labor reduction among children of parents with low levels of education.

-Table 6 about here-

\section{Extensions: labor migration and gender}

We now explore heterogenous and asymmetric effects in children's labor supply according to both the gender of the migrants and the gender of the child. About the 
latter, we consider separately male and female children as to explore differences in parental decisions on time allocation by child gender. The latter may be due to different labor market returns between male and female children or to gender-specific parental preferences over child's time use (Edmonds, 2008a). We hence estimate the same model as in the former section on different sub-samples while using data for the 2000. Table 7 reports heterogenous migration results by child gender. While the average estimated coefficient of the emigration index in low-skilled households is not significantly different across males and females, there is a significant compositional effect across the two child sub-samples. Higher relative low-skilled emigration is associated to a bigger reduction in child labor supply in domestic work for males than for females, while the coefficient on female children is almost entirely driven by the reduction of market and family business works. This is also consistent with expectations since, compared to boys, girls generally have higher participation rates in domestic work and lower participation rates in market work.

-Table 7 about here-

We also consider the asymmetric effect of gender-specific emigration supply shocks on child labor by using the gender dimension of the country level migration dataset. This is of interest as the increasing participation of women in international migration raises specific concerns related to the gendered consequences of migration in terms of wellbeing and human capital formation of future generations (Docquier et al, 2007, Cortes, 2013). This is so as women typically face unequal access to the labor market in less developed contexts such that female emigration may generate lower relative gains than the emigration of males. At the same time though, well-documented different roles of women as economic agents and their preferences for investing resources in child well-being may lead to gender differentials in the economic consequences of labor out-migration on children's time use (World Bank, 2007; Thomas, 1990).

Thus, we analyse the same relationship between emigration supply shocks and child time allocation as above, while considering heterogenous labor on the basis of both individual skill and gender of workers. If males and females compete on different 
labor markets, female (male) out-migration will directly affect female (male) economic conditions and hence we may observe a gender-specific effect on child labor supply according to the gender of the parent. Therefore, we estimate a child labor equation where our coefficient of interest is the interaction between parental skill/gender type and the country-level measure of the gender-specific emigration-induced pressure on the local labor market. The latter variable is the gender-specific RSC index ${ }^{28}$ while the gender of the parent is defined on the MICS sample of children with both parents (i.e. we drop single headed households) where male parent is identified by the male household head and the female parent is the 'woman in charge', i.e. the primary care taker of the child. Results are reported in Table 8. Overall, there are little or no gender differentials in the labor market effect of emigration supply shocks on child labor in each different work activity. When considering the most generic extensive indicator of child labor though, results are more precisely estimated in the male subsample. This may be due to the fact that, compared to women, men typically face more favourable labor market conditions and therefore they gain relatively more when male outmigration reduces labor supply.

-Tables 8 about here-

\section{Conclusions}

Child labor is widespread and a poverty-related phenomenon that has short- and long-term detrimental implications for individual well-being (Edmonds and Pavcnick, 2005b). Globalization in general, and international migration flows in particular, may lead to a greater demand for both adult and child labor. However, the emigration supply shock in the adult labor force can raise family earnings in a way that tends to reduce child labor. Thus, wokers' mobility across national borders may have an ambiguous impact on child labor through chages in the competitive labor market.

\footnotetext{
${ }^{28}$ The gender-specific RSC index is $\left(\frac{m_{i j}^{\text {low }}}{1-m_{i j}^{\text {low }}} / \frac{l f_{i j}^{\text {low }}}{1-l f_{i j}^{\text {low }}}\right)$, that is the ratio of unskilled to skilled labor in the migrant relative to the stayer populations of gender $i$ in country $j$, where $i$ is equal to either female or male.
} 
We use an original dataset, which combines information on international outmigration from a wide range of developing countries with detailed individual- and household-level survey data on child labor in each country, to investigate children's work response to emigration shocks, accounting for the skill composition of both the migrant and the resident labor force.

Our empirical strategy builds on standard trade and labor-economics theory according to which the distributional effects of migration through wages depend crucially on changes in the relative labor supply due to migration, i.e. on the relative skills of migrant to native workers (Borjas, 1999). Hence, provided that child time allocation is a decision taken by parent(s), we estimate a set of child labor equations where the variable of interest is the interactive effect between the parental skilllevel and the relative skill composition (RSC) of emigrants with respect to resident workers. Overall, our findings show that the labor market competition induced by emigration may significantly reduce or offset the potential increase of child labor associated with low parental education, i.e. with poor labor market conditions. Indeed, ceteris paribus, low-skilled households heads are more likely to send their children to work, but this effect is strongly negative and significant the lower is the relative skill composition of the migrant to resident labor force. Results are robust to controlling for a large set of individual-level characteristics, interactive effects of remittances, country fixed effects, and to the use of an instrumental variable estimator based on lagged emigration supply shocks. Finding that the cross-country variation in the correlation between parental skill and child labor is related to differences in the skill composition of emigrant relative to resident workers points to a significant role of the labor market mechanism induced by emigration in shaping child time allocation.

Our findings add up to recent evidence on the labor market impact of emigration on households at origin and on the relationship between globalization, growth, and poverty in developing countries. Overall, if poverty and child labor reduction are policy goals, improving labor market integration and removing barriers to crossborder mobility of workers may hit some of the economic roots of child labor in developing countries. 


\section{References}

Aydemir A., Borjas G.J. (2007), Cross-Country Variation in the Impact of International Migration: Canada, Mexico, and the United States, Journal of the European Economic Association, Vol. 5, No. 4: pp. 663-708.

Basu K., Van P. (1998). The Economics of Child Labor. American Economic Review, 88(3), pp. 412-27.

Beegle K., Dehejia R., Gatti R. (2009), Why should we care about child labor? The education, labor market and health consequences of child labor, Journal of Human Resources, Vol. 44(4), pp. 871-889.

Borjas G.J. (1995), The economic beneifts from immigration, Journal of Economic Perspective, American Economic Association, vol. 9(2), pages 3-22, Spring.

Borjas G.J. (1999), The economic analysis of immigration, Handbook of Labor Economics, edition 1, Vol. 3, chapter 28, pp 1697-1760.

Borjas G.J. (2003), The Labor Demand Curve Is Downward Sloping: Reexamining the Impact of Immigration on the Labor Market, Quarterly Journal of Economics, Vol. 118(4), pp. 1335-74.

Borjas G.J. (2008), Labor outflows and inflows in Puerto-Rico, Journal of Human Capital, Vol. 2, No. 1: pp. 32-68

Bouton L., Paul S., Tiongson E.R. (2011), The impact of emigration on source countries wages: evidence from the Republic of Moldova, Policy Research Working Paper n. 5764, The World Bank

Card D. (2001), Immigrant Inflows, Native Outflows, and the Local Labor Market Impacts of Higher Immigration, Journal of Labor Economics, University of Chicago Press, vol. 19(1), pp 22-64, January.

Card D. (2005), Is the New Immigration Really so Bad?, Economic Journal, Royal Economic Society, vol. 115(507), pp F300-F323, November.

Chiquiar D. (2008), Globalization, regional wage differentials and the StolperSamuelson Theorem: Evidence from Mexico,Journal of International Economics, Elsevier, vol. 74(1), pages 70-93, January.

Cigno A., Rosati F.C. (2005). The Economics of Child Labor, Oxford University 
Press.

Cigno A., Rosati F.C., Tzannatos Z. (2002), Child labor handbook, Social Protection Discussion Papers 25507, The World Bank.

Cigno A., Rosati F.C., Guarcello L. (2002), Does globalization increase child labor?, World Development 30, pp. 1579-1589.

Cortes P. (2013), The Feminization of International Migration and its effects on the Children Left behind: Evidence from the Philippines, World Development, forthcoming.

Cox Edwards A., Ureta M. (2003). International Migration, Remittances, and Schooling: evidence from El Salvador, NBER WP n. w9766.

Dinopoulos E., Zhao L. (2007), Child Labor and Globalization. Journal of Labor Economics, 25(3), pp. 553-580.

Docquier, F., Lowell B.L. and Marfouk, A. (2007), A gendered assessment of highly skilled emigration, Population and Development Review (2009), 35 (2), 297322.

Dustmann C., Frattini T., Rosso A. (2012), The effect of emigration from Poland on Polish wages, CReAM Discussion Paper Series 1229, Department of Economics, CReAM University College London.

Edmonds E. (2008a), Child Labor, Handbook of Development Economics, Elsevier.

Edmonds E. (2008b), Defining child labour: a review of the definitions of child laobur in policy research, ILO WP.

Edmonds E., Pavcnik N. (2006). International trade and child labor: crosscountry evidence. Journal of International Economics, 68 (1), pp. 115-140.

Edmonds E., Pavcnik N. (2005a) The Effect of Trade Liberalization on Child Labor. Journal of International Economics 65(2), 401-419.

Edmonds E., Pavcnik N. (2005b), Child Labor in the Global Economy, Journal of Economic Perspectives, 18(1), pp. 199-220.

Edmonds E., Shrestha M. (2012), The impact of minimum age of employment regulation on child labor and schooling: evidence from UNICEF MICS countries, 
NBER WP n. 18623.

Elsner, B. (2013), Emigration and Wages: The EU Enlargement Experiment, Journal of International Economics, 2013, 91(1), 154-163.

Emerson P., Portela Souza A. (2011), Is Child Labor Harmful? The Impact of Working Earlier in Life on Adult Earnings, Economic Development and Cultural Change, University of Chicago Press, vol. 59(2), pages 345 - 385.

Epstein G., Kahana N. (2008) Child Labor and Temporary Emigration, Economics Letters, 99(3), pp. 545- 548.

Gagnon J. (2011), 'Stay with us?' The impact of emigration on wages in Honduras, OECD Development Centre Working Paper 300, OECD Publishing.

Goldin (1979), Household and market production of families in a late nineteenth century city, Explorations in Economic History, Vol. 16, pp 111-131.

Hanson G. (2004), What Has Happened to Wages in Mexico since NAFTA?, in Toni Estevadeordal, Dani Rodrik, Alan Taylor, Andres Velasco, eds., FTAA and Beyond: Prospects for Integration in the Americas, Cambridge: Harvard University Press.

Hanson, G (2006), Emigration, Labor Supply, and Earnings in Mexico, chapter in Mexican Immigration to the United States, NBER, University of Chicago Press.

Hanson G. (2007), Emigration, Remittances, and Labor Force Participation in Mexico, Integration and Trade Journal, 27, pp. 73-103.

Hanson G. (2008), The Economic Consequences of the International Migration of Labor, Annual Review of Economics, 1(2009): 179-208.

Krugman P., Obstfeld M. (2006), International Economics: Theory and Policy, 7th Edition.

Levy V. (1985), Cropping Pattern, Mechanization, Child Labor, and Fertility Behavior in a Farming Economy: Rural Egypt,Economic Development and Cultural Change, University of Chicago Press, vol. 33(4), pages 777-91, July.

Lopez Cordoba E. (2004), Globalization, Migration, and Development: the role of Mexican migrant remittances, Econometric Society 2004 Latin American Meetings 82, Econometric Society. 
Lucas, Robert E B, (1987). Emigration to South Africa's Mines, American Economic Review, American Economic Association, vol. 77(3), pages 313-30, June.

Manacorda, M. and Rosati, F. (2010). Local labor Demand and Child Labor. Research in Labor Economics, 31.

Mansuri, G. (2006). Migration, school attainment and child labor: Evidence from rural Pakistan. World Bank Policy Research Working Paper 3945. Washington, DC: World Bank.

Mayda A.M. (2006), Who is against immigration? A cross-country investigation of individual attitudes toward immigrants, The Review of Economic and Statistics, Vol. 88(3), pp 510-530.

Mishra, P. (2007), Emigration and wages in source countries: Evidence from Mexico, Journal of Development Economics, Vol. 82, pp 180-199.

Oostendorp R. H. (2012), The Occupational Wages around the World (OWW) Database: Update for 1983-2008. Background paper for the World Development Report 2013.

Parikh A., Sadoulet E. (2005), The effect of parents' occupation on child labor and school attendance in Brazil, Working Paper no. 1000 (UC Berkeley).

Prichett L. (2006), Let their people come: breaking the gridlock on global labor mobility, Center for global development, Washington D.C.

Robertson R. (2000), Wage Shocks and North American Labor-Market Integration, American Economic Review, Vol. 90(4), pp 742-764.

Rosenzweig M., Evenson R. (1977), Fertility, Schooling, and the Economic Contribution of Children in Rural India: An Econometric Analysis, Econometrica, Econometric Society, vol. 45(5), pages 1065-79, July.

Scheve K. F., Slaughter M. J. (2001), Labor Market Competition and Individual Preferences over Immigration Policy, Review of Economics and Statistics 83 (1): 13345

Skoufias E. (1993), Labor market opportunities and intrafamily time allocation in rural households in South Asia, Journal of Development Economics, Elsevier, vol. 40(2), pages 277-310, April. 
Thomas D. (1990), Intra-Household Resource Allocation: An Inferential Approach, Journal of Human Resources, University of Wisconsin Press, vol. 25(4), pages $635-664$.

World Bank (2007), Confronting the challenges of gender equality and fragile states, Global Monitoring Report, Washington: The World Bank.

Yang D. (2004), International Migration, Human Capital, and Entrepreneurship: Evidence from Philippine Migrants' Exchange Rate Shocks, Working Papers 531, Research Seminar in International Economics, University of Michigan.

Yang D. (2008), International Migration, Remittances and Household Investment: Evidence from Philippine Migrants' Exchange Rate Shocks, Economic Journal, Royal Economic Society, vol. 118(528), pages 591-630, 04. 
Table 1 - Country level summary statistics (2000)

\begin{tabular}{|c|c|c|c|c|}
\hline & Child Labor (\%) & Migration rate (\%) & RSC Index & Remittances (as \% of GDP) \\
\hline Albania & 11.9 & 19.1 & 0.87 & 16.22 \\
\hline Angola & 16.1 & 1.0 & 0.74 & \\
\hline Azerbaijan & 7.6 & 0.6 & 0.52 & 1.08 \\
\hline Bolivia & 18.4 & 1.8 & 0.10 & 1.51 \\
\hline Bosnia and Herzegovina & 3.1 & 16.2 & 0.78 & 0.03 \\
\hline Burundi & 17.6 & 0.4 & 0.04 & \\
\hline Cameroon & 36.5 & 0.8 & 0.07 & 0.11 \\
\hline Central African Republic & 39.9 & 0.4 & 0.07 & \\
\hline Chad & 30.7 & 0.1 & 0.02 & \\
\hline Comoros & 10.2 & 3.9 & 0.49 & 5.94 \\
\hline Congo, Dem. Rep. of the & 12.5 & 0.5 & 0.12 & \\
\hline Cote d'Ivoire & 28.3 & 0.7 & 0.24 & 1.14 \\
\hline Dominican Republic & 5.0 & 13.6 & 0.40 & 0.01 \\
\hline Equatorial Guinea & 23.6 & 5.5 & 0.09 & \\
\hline Gambia, The & 13.9 & 3.0 & 0.11 & 3.33 \\
\hline Guinea-Bissau & 23.1 & 3.6 & 0.25 & 0.93 \\
\hline Guyana & 7.1 & 43.0 & 0.29 & 3.79 \\
\hline Iraq & 14.7 & 2.6 & 0.25 & \\
\hline Kenya & 19.6 & 1.7 & 0.05 & 4.24 \\
\hline Laos & 19.5 & 10.1 & 0.37 & 0.06 \\
\hline Lesotho & 10.9 & 0.1 & 0.05 & 33.78 \\
\hline Madagascar & 5.3 & 0.5 & 0.10 & 0.28 \\
\hline Moldova & 26.5 & 1.6 & 0.69 & 13.90 \\
\hline Mongolia & 31.8 & 0.3 & 0.03 & 1.06 \\
\hline Niger & 41.0 & 0.1 & 0.02 & 0.78 \\
\hline Philippines & 5.1 & 5.0 & 0.23 & 0.01 \\
\hline Rwanda & 33.3 & 0.5 & 0.01 & 0.40 \\
\hline Sao Tome and Principe & 7.6 & 10.9 & 0.61 & \\
\hline Senegal & 27.2 & 2.5 & 0.21 & 4.97 \\
\hline Sierra Leone & 24.5 & 2.0 & 0.03 & 1.10 \\
\hline Sudan & 10.5 & 0.3 & 0.05 & 5.18 \\
\hline Swaziland & 5.2 & 0.5 & 0.15 & 4.97 \\
\hline Tajikistan & 23.0 & 0.2 & 0.69 & \\
\hline Togo & 52.7 & 1.1 & 0.14 & 2.56 \\
\hline Trinidad and Tobago & 1.4 & 25.3 & 0.29 & 0.47 \\
\hline Uzbekistan & 16.8 & 0.3 & 0.58 & \\
\hline Venezuela & 3.8 & 1.3 & 0.06 & 0.01 \\
\hline Vietnam & 23.8 & 3.4 & 0.13 & 0.01 \\
\hline Mean & 18.68 & 4.85 & 0.26 & 3.85 \\
\hline St. dev & 12.20 & 8.65 & 0.25 & 7.08 \\
\hline Min & 1.44 & 0.07 & 0.01 & 0.01 \\
\hline Max & 52.68 & 43.04 & 0.87 & 33.78 \\
\hline
\end{tabular}


Table 2 - Child-level summary statistics

\begin{tabular}{|c|c|c|c|}
\hline & $\begin{array}{c}\text { Non working } \\
\text { children }\end{array}$ & $\begin{array}{l}\text { Working } \\
\text { children }\end{array}$ & Total \\
\hline $\begin{array}{l}\text { Household head }(\mathrm{HhH}) \text { with primary } \\
\text { education }(\%)\end{array}$ & 64 & 73 & 66 \\
\hline Age & 8.95 & 10.68 & 9.31 \\
\hline Male (\%) & 50 & 50 & 50 \\
\hline HhH male (\%) & 84 & 86 & 85 \\
\hline Mother dead (\%) & 3 & 4 & 3 \\
\hline Mother absent (\%) & 10 & 12 & 10 \\
\hline Mother in the Hh (\%) & 87 & 84 & 87 \\
\hline Father dead (\%) & 7 & 8 & 7 \\
\hline Father absent (\%) & 16 & 16 & 16 \\
\hline Father in the Hh (\%) & 77 & 76 & 77 \\
\hline Family size & 8.03 & 8.55 & 8.13 \\
\hline N. of children $<5$ y.o. at home & 1.19 & 1.25 & 1.20 \\
\hline Urban area (\%) & 40 & 23 & 36 \\
\hline Missing information on area & 2 & 0 & 2 \\
\hline \multicolumn{4}{|l|}{ Wealth index distribution (\%): } \\
\hline Missing info on wealth & 5 & 2 & 4 \\
\hline 1st quantile & 20 & 29 & 22 \\
\hline 2nd quantile & 19 & 24 & 20 \\
\hline 3rd quantile & 19 & 21 & 19 \\
\hline 4th quantile & 19 & 15 & 18 \\
\hline 5th quintile & 18 & 9 & 17 \\
\hline Child labor last week (\%) & & & 21 \\
\hline Child labor in market work (\%) & & & 6 \\
\hline Child labor in family business (\%) & & & 5 \\
\hline Child labor in chores (\%) & & & 7 \\
\hline Children attending school this year (\%) & & & 77 \\
\hline $\begin{array}{l}\text { Children attending school \& working (generic } \\
\text { work) (\%) }\end{array}$ & & & 15 \\
\hline Total obs & 268416 & 69677 & 338093 \\
\hline
\end{tabular}


Table 3 - Individual determinants of child labor

\begin{tabular}{|c|c|c|c|c|c|c|c|c|c|}
\hline & Any work & $\begin{array}{c}\text { (2) } \\
\text { Total } \\
\text { hours of } \\
\text { work }\end{array}$ & $\begin{array}{l}\text { Market } \\
\text { work }\end{array}$ & $\begin{array}{c}(4) \\
\text { Hours in } \\
\text { market } \\
\text { work }\end{array}$ & $\begin{array}{c}\text { (5) } \\
\text { Family } \\
\text { business }\end{array}$ & $\begin{array}{c}\text { (6) } \\
\text { Hours in } \\
\text { family } \\
\text { business }\end{array}$ & Chores & $\begin{array}{c}\text { Hours in } \\
\text { chores }\end{array}$ & $\begin{array}{l}\text { School } \\
\text { attendance }\end{array}$ \\
\hline HhH low-skilled & $\begin{array}{c}0.028 * * * \\
(0.005)\end{array}$ & $\begin{array}{c}1.644^{* * *} \\
(0.336)\end{array}$ & $\begin{array}{c}0.013 * * * \\
(0.004)\end{array}$ & $\begin{array}{c}0.861 * * * \\
(0.236)\end{array}$ & $\begin{array}{c}0.009 * * * \\
(0.003)\end{array}$ & $\begin{array}{c}0.586^{* * *} \\
(0.174)\end{array}$ & $\begin{array}{c}0.010 * * * \\
(0.003)\end{array}$ & $\begin{array}{c}0.574 * * * \\
(0.158)\end{array}$ & $\begin{array}{c}-0.040 * * * \\
(0.009)\end{array}$ \\
\hline Age & $\begin{array}{c}0.037 * * * \\
(0.004)\end{array}$ & $\begin{array}{c}2.579 * * * \\
(0.232)\end{array}$ & $\begin{array}{c}0.013 * * * \\
(0.002)\end{array}$ & $\begin{array}{c}0.985 * * * \\
(0.125)\end{array}$ & $\begin{array}{c}0.010^{* * *} \\
(0.002)\end{array}$ & $\begin{array}{c}0.741^{* * * *} \\
(0.095)\end{array}$ & $\begin{array}{c}0.014 * * * \\
(0.002)\end{array}$ & $\begin{array}{c}1.211^{* * *} \\
(0.119)\end{array}$ & $\begin{array}{c}0.006 \\
(0.006)\end{array}$ \\
\hline Male & $\begin{array}{l}-0.005 \\
(0.005)\end{array}$ & $\begin{array}{c}-0.825 * * \\
(0.390)\end{array}$ & $\begin{array}{c}0.017 * * * \\
(0.005)\end{array}$ & $\begin{array}{c}1.234 * * * \\
(0.321)\end{array}$ & $\begin{array}{c}0.014 * * * \\
(0.005)\end{array}$ & $\begin{array}{c}0.934 * * * \\
(0.303)\end{array}$ & $\begin{array}{c}-0.040 * * * \\
(0.007)\end{array}$ & $\begin{array}{c}-2.902 * * * \\
(0.442)\end{array}$ & $\begin{array}{c}0.021 \\
(0.015)\end{array}$ \\
\hline HhH male & $\begin{array}{c}0.017 * * * \\
(0.003)\end{array}$ & $\begin{array}{c}1.119 * * * \\
(0.202)\end{array}$ & $\begin{array}{c}0.006^{* *} \\
(0.002)\end{array}$ & $\begin{array}{c}0.419 * * * \\
(0.112)\end{array}$ & $\begin{array}{c}0.006^{* *} \\
(0.002)\end{array}$ & $\begin{array}{c}0.384 * * * \\
(0.121)\end{array}$ & $\begin{array}{c}0.008 * * * \\
(0.002)\end{array}$ & $\begin{array}{c}0.502^{* * *} \\
(0.109)\end{array}$ & $\begin{array}{l}-0.006 \\
(0.005)\end{array}$ \\
\hline Mother dead & $\begin{array}{c}0.007 \\
(0.006)\end{array}$ & $\begin{array}{c}0.398 \\
(0.374)\end{array}$ & $\begin{array}{c}0.001 \\
(0.005)\end{array}$ & $\begin{array}{c}0.123 \\
(0.275)\end{array}$ & $\begin{array}{l}-0.002 \\
(0.004)\end{array}$ & $\begin{array}{l}-0.003 \\
(0.188)\end{array}$ & $\begin{array}{c}0.007 * * * \\
(0.002)\end{array}$ & $\begin{array}{c}0.369 * * \\
(0.147)\end{array}$ & $\begin{array}{c}-0.021^{* * *} \\
(0.007)\end{array}$ \\
\hline Mother absent & $\begin{array}{c}0.007 \\
(0.005)\end{array}$ & $\begin{array}{c}0.406 \\
(0.260)\end{array}$ & $\begin{array}{c}0.002 \\
(0.002)\end{array}$ & $\begin{array}{l}-0.014 \\
(0.135)\end{array}$ & $\begin{array}{c}0.000 \\
(0.002)\end{array}$ & $\begin{array}{l}-0.107 \\
(0.106)\end{array}$ & $\begin{array}{c}0.005 * * \\
(0.003)\end{array}$ & $\begin{array}{c}0.379 * * \\
(0.149)\end{array}$ & $\begin{array}{c}-0.012 * \\
(0.006)\end{array}$ \\
\hline Father dead & $\begin{array}{l}-0.001 \\
(0.004)\end{array}$ & $\begin{array}{l}-0.155 \\
(0.209)\end{array}$ & $\begin{array}{l}-0.000 \\
(0.002)\end{array}$ & $\begin{array}{l}-0.138 \\
(0.126)\end{array}$ & $\begin{array}{l}-0.001 \\
(0.002)\end{array}$ & $\begin{array}{l}-0.197 \\
(0.118)\end{array}$ & $\begin{array}{l}-0.001 \\
(0.003)\end{array}$ & $\begin{array}{c}0.009 \\
(0.138)\end{array}$ & $\begin{array}{c}-0.016 * * * \\
(0.005)\end{array}$ \\
\hline Father absent & $\begin{array}{l}-0.002 \\
(0.006)\end{array}$ & $\begin{array}{l}-0.168 \\
(0.351)\end{array}$ & $\begin{array}{l}-0.003 \\
(0.003)\end{array}$ & $\begin{array}{l}-0.171 \\
(0.169)\end{array}$ & $\begin{array}{c}-0.005^{* *} \\
(0.002)\end{array}$ & $\begin{array}{c}-0.300 * * \\
(0.130)\end{array}$ & $\begin{array}{l}-0.000 \\
(0.003)\end{array}$ & $\begin{array}{c}0.060 \\
(0.200)\end{array}$ & $\begin{array}{l}-0.008 * \\
(0.004)\end{array}$ \\
\hline Family size & $\begin{array}{c}-0.002 \\
(0.001)\end{array}$ & $\begin{array}{c}-0.118^{* *} \\
(0.057)\end{array}$ & $\begin{array}{l}-0.000 \\
(0.001)\end{array}$ & $\begin{array}{c}-0.014 \\
(0.031)\end{array}$ & $\begin{array}{c}0.000 \\
(0.000)\end{array}$ & $\begin{array}{c}0.013 \\
(0.025)\end{array}$ & $\begin{array}{c}-0.002 * * * \\
(0.001)\end{array}$ & $\begin{array}{c}-0.136 * * * \\
(0.027)\end{array}$ & $\begin{array}{c}0.001^{* *} \\
(0.001)\end{array}$ \\
\hline $\begin{array}{l}\text { N. of children }<5 \\
\text { y.o. at home }\end{array}$ & $\begin{array}{c}0.008 * * * \\
(0.002)\end{array}$ & $\begin{array}{c}0.535 * * * \\
(0.137)\end{array}$ & $\begin{array}{c}0.003 * * * \\
(0.001)\end{array}$ & $\begin{array}{c}0.169 * * * \\
(0.054)\end{array}$ & $\begin{array}{c}0.002 * * \\
(0.001)\end{array}$ & $\begin{array}{c}0.107^{* *} \\
(0.049)\end{array}$ & $\begin{array}{c}0.005 * * * \\
(0.001)\end{array}$ & $\begin{array}{c}0.337 * * * \\
(0.087)\end{array}$ & $\begin{array}{c}-0.011 * * * \\
(0.004)\end{array}$ \\
\hline Urban area & $\begin{array}{c}-0.096 * * * \\
(0.011)\end{array}$ & $\begin{array}{c}-5.803 * * * \\
(0.645)\end{array}$ & $\begin{array}{c}-0.031^{* * *} \\
(0.005)\end{array}$ & $\begin{array}{c}-2.743^{* * *} \\
(0.396)\end{array}$ & $\begin{array}{c}-0.030 * * * \\
(0.005)\end{array}$ & $\begin{array}{c}-2.657 * * * \\
(0.381)\end{array}$ & $\begin{array}{c}-0.018^{* * *} \\
(0.003)\end{array}$ & $\begin{array}{c}-1.314^{* * *} \\
(0.148)\end{array}$ & $\begin{array}{c}0.012 \\
(0.011)\end{array}$ \\
\hline $\begin{array}{l}\text { Missing info on } \\
\text { area }\end{array}$ & $\begin{array}{l}-0.030 \\
(0.023)\end{array}$ & $\begin{array}{c}-3.861^{* * *} \\
(1.008)\end{array}$ & $\begin{array}{c}-0.051^{* * *} \\
(0.005)\end{array}$ & $\begin{array}{c}-1.840^{* * *} \\
(0.243)\end{array}$ & $\begin{array}{c}-0.047^{* * *} \\
(0.007)\end{array}$ & $\begin{array}{c}-1.564^{* * *} \\
(0.219)\end{array}$ & $\begin{array}{c}-0.053^{* * *} \\
(0.014)\end{array}$ & $\begin{array}{l}-1.316^{*} \\
(0.700)\end{array}$ & $\begin{array}{l}-0.001 \\
(0.023)\end{array}$ \\
\hline $\begin{array}{l}\text { Missing info on } \\
\text { wealth }\end{array}$ & $\begin{array}{c}0.077 * * * \\
(0.023)\end{array}$ & $\begin{array}{c}4.542 * * * \\
(1.029)\end{array}$ & $\begin{array}{c}0.032 * * * \\
(0.007)\end{array}$ & $\begin{array}{c}1.987 * * * \\
(0.354)\end{array}$ & $\begin{array}{c}0.024 * * * \\
(0.007)\end{array}$ & $\begin{array}{c}1.580 * * * \\
(0.300)\end{array}$ & $\begin{array}{l}0.027^{*} \\
(0.014)\end{array}$ & $\begin{array}{l}1.171 \\
(0.698)\end{array}$ & $\begin{array}{c}-0.088 * * * \\
(0.017)\end{array}$ \\
\hline 1st quantile & $\begin{array}{c}0.100 * * * \\
(0.012)\end{array}$ & $\begin{array}{c}6.913 * * * \\
(0.730)\end{array}$ & $\begin{array}{c}0.050 * * * \\
(0.008)\end{array}$ & $\begin{array}{c}3.715^{* * * *} \\
(0.490)\end{array}$ & $\begin{array}{c}0.039 * * * \\
(0.006)\end{array}$ & $\begin{array}{c}3.028 * * * \\
(0.410)\end{array}$ & $\begin{array}{c}0.024 * * * \\
(0.005)\end{array}$ & $\begin{array}{c}1.711^{* * *} \\
(0.317)\end{array}$ & $\begin{array}{c}-0.100 * * * \\
(0.019)\end{array}$ \\
\hline 2nd quantile & $\begin{array}{c}0.075^{* * *} \\
(0.012)\end{array}$ & $\begin{array}{c}5.243^{* * * *} \\
(0.825)\end{array}$ & $\begin{array}{c}0.039 * * * \\
(0.008)\end{array}$ & $\begin{array}{c}2.859 * * * \\
(0.511)\end{array}$ & $\begin{array}{c}0.029 * * * \\
(0.006)\end{array}$ & $\begin{array}{c}2.246 * * * \\
(0.446)\end{array}$ & $\begin{array}{c}0.015^{* * * *} \\
(0.005)\end{array}$ & $\begin{array}{c}1.146 * * * \\
(0.302)\end{array}$ & $\begin{array}{c}-0.062 * * * \\
(0.019)\end{array}$ \\
\hline 3rd quantile & $\begin{array}{c}0.061^{* * *} \\
(0.012)\end{array}$ & $\begin{array}{c}4.198 * * * \\
(0.776)\end{array}$ & $\begin{array}{c}0.030 * * * \\
(0.007)\end{array}$ & $\begin{array}{c}2.165^{* * *} \\
(0.428)\end{array}$ & $\begin{array}{c}0.020^{* * *} \\
(0.005)\end{array}$ & $\begin{array}{c}1.605^{* * *} \\
(0.374)\end{array}$ & $\begin{array}{c}0.014^{* * *} \\
(0.004)\end{array}$ & $\begin{array}{c}1.037 * * * \\
(0.266)\end{array}$ & $\begin{array}{c}-0.045^{* * *} \\
(0.013)\end{array}$ \\
\hline 4th quantile & $\begin{array}{c}0.032 * * * \\
(0.010)\end{array}$ & $\begin{array}{c}2.452 * * * \\
(0.681)\end{array}$ & $\begin{array}{c}0.019 * * * \\
(0.006)\end{array}$ & $\begin{array}{c}1.241 * * * \\
(0.382)\end{array}$ & $\begin{array}{l}0.013^{* *} \\
(0.005)\end{array}$ & $\begin{array}{l}0.900 * * \\
(0.340)\end{array}$ & $\begin{array}{l}0.007 * \\
(0.004)\end{array}$ & $\begin{array}{l}0.644 * * \\
(0.243)\end{array}$ & $\begin{array}{c}-0.028 * * * \\
(0.007)\end{array}$ \\
\hline $\begin{array}{l}\text { ILO conventions } \\
\text { binding }\end{array}$ & $\begin{array}{l}-0.003 \\
(0.037)\end{array}$ & $\begin{array}{l}-0.576 \\
(2.311)\end{array}$ & $\begin{array}{l}-0.002 \\
(0.028)\end{array}$ & $\begin{array}{l}-0.174 \\
(1.601)\end{array}$ & $\begin{array}{c}0.000 \\
(0.024)\end{array}$ & $\begin{array}{c}0.263 \\
(1.241)\end{array}$ & $\begin{array}{l}-0.011 \\
(0.025)\end{array}$ & $\begin{array}{l}-0.612 \\
(1.099)\end{array}$ & $\begin{array}{c}0.007 \\
(0.054)\end{array}$ \\
\hline $\begin{array}{l}\text { Internal empl. } \\
\text { regulation binding }\end{array}$ & $\begin{array}{l}-0.018 \\
(0.019)\end{array}$ & $\begin{array}{l}-1.015 \\
(1.245)\end{array}$ & $\begin{array}{l}-0.019 \\
(0.015)\end{array}$ & $\begin{array}{l}-1.095 \\
(0.814)\end{array}$ & $\begin{array}{l}-0.013 \\
(0.010)\end{array}$ & $\begin{array}{l}-0.737 \\
(0.570)\end{array}$ & $\begin{array}{l}-0.019 \\
(0.014)\end{array}$ & $\begin{array}{l}-0.339 \\
(0.692)\end{array}$ & $\begin{array}{c}0.021 \\
(0.030)\end{array}$ \\
\hline $\begin{array}{l}\text { Below compulsory } \\
\text { school MLA }\end{array}$ & $\begin{array}{c}0.020 \\
(0.022)\end{array}$ & $\begin{array}{l}2.096 \\
(1.416)\end{array}$ & $\begin{array}{c}0.011 \\
(0.015)\end{array}$ & $\begin{array}{l}0.675 \\
(0.872)\end{array}$ & $\begin{array}{c}0.007 \\
(0.011)\end{array}$ & $\begin{array}{c}0.553 \\
(0.627)\end{array}$ & $\begin{array}{c}0.011 \\
(0.012)\end{array}$ & $\begin{array}{l}1.312 * * \\
(0.601)\end{array}$ & $\begin{array}{c}0.141 * * * \\
(0.044)\end{array}$ \\
\hline $\begin{array}{l}\text { Observations } \\
\text { R-squared }\end{array}$ & $\begin{array}{l}338,093 \\
0177\end{array}$ & $\begin{array}{l}338,093 \\
0243\end{array}$ & $\begin{array}{l}338,093 \\
0086\end{array}$ & 338,093 & $\begin{array}{l}338,093 \\
0067\end{array}$ & 338,093 & $\begin{array}{l}338,093 \\
0073\end{array}$ & $\begin{array}{l}338,093 \\
0175\end{array}$ & $\begin{array}{l}113,920 \\
0462\end{array}$ \\
\hline $\begin{array}{l}\text { Robust standard errc } \\
\text { Notes: Dependent v } \\
\text { School attendance } \\
\text { countries. Referenc } \\
\text { 'female', 'female ho }\end{array}$ & rs are rep & ted in pare & es, clu & red at th & ountry lev & $* * * \mathrm{p}<0$ & $* * \mathrm{p}<0$ & $* \mathrm{p}<0.1$ & i.e. hour \\
\hline
\end{tabular}


Table 4 - Migration relative skill composition (RSC) and child labor (largest sample)

\begin{tabular}{lcccccccccc}
\hline & $(1)$ & $\begin{array}{c}(2) \\
\text { Tny }\end{array}$ & $\begin{array}{c}\text { Total } \\
\text { hours of } \\
\text { work }\end{array}$ & $\begin{array}{c}\text { Market } \\
\text { work }\end{array}$ & $\begin{array}{c}\text { Hours in } \\
\text { market } \\
\text { work }\end{array}$ & $\begin{array}{c}\text { Family } \\
\text { business }\end{array}$ & $\begin{array}{c}\text { Hours in } \\
\text { family } \\
\text { business }\end{array}$ & Chores & $\begin{array}{c}\text { Hours in } \\
\text { chores }\end{array}$ & $\begin{array}{c}\text { School } \\
\text { attendance }\end{array}$ \\
\hline RSC*HhH low-skill & $-0.056^{* *}$ & $-4.177^{* *}$ & $-0.042^{* *}$ & $-2.727^{* *}$ & $-0.033^{* *}$ & $-1.898^{* *}$ & $-0.032^{* *}$ & $-1.311^{* *}$ & $0.080^{* *}$ \\
& $(0.026)$ & $(1.566)$ & $(0.018)$ & $(1.102)$ & $(0.015)$ & $(0.849)$ & $(0.012)$ & $(0.571)$ & $(0.031)$ \\
HhH low-skilled & $0.038^{* * *}$ & $2.359^{* * *}$ & $0.020^{* * *}$ & $1.328^{* * *}$ & $0.015^{* * *}$ & $0.911^{* * *}$ & $0.016^{* * *}$ & $0.798^{* * *}$ & $-0.056^{* * *}$ \\
& $(0.007)$ & $(0.471)$ & $(0.006)$ & $(0.375)$ & $(0.005)$ & $(0.271)$ & $(0.004)$ & $(0.189)$ & $(0.012)$
\end{tabular}

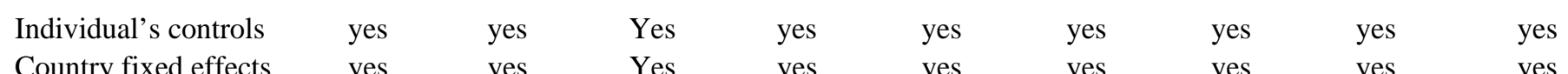

$\begin{array}{lccccccccc}\text { Country fixed effects } & \text { yes } & \text { yes } & \text { Yes } & \text { yes } & \text { yes } & \text { yes } & \text { yes } & \text { yes } & \text { yes } \\ \text { Observations } & 338,093 & 338,093 & 338,093 & 338,093 & 338,093 & 338,093 & 338,093 & 338,093 & 113,920\end{array}$

\begin{tabular}{lccccccccc} 
Observations & 338,093 & 338,093 & 338,093 & 338,093 & 338,093 & 338,093 & 338,093 & 338,093 & 113,920 \\
R-squared & 0.177 & 0.244 & 0.086 & 0.134 & 0.067 & 0.114 & 0.073 & 0.175 & 0.462 \\
\hline
\end{tabular}

Robust standard errors are reported in parentheses, clustered at the country level. $* * * p<0.01, * * p<0.05, * p<0.1$ Notes: Dependent

variables are dichotomous indicators for working more than 28 hours and continuous indicators (i.e. hours). School attendance is a

dichotomous variable referred to the current year. The sample includes children aged 5-14 in 38 countries. The Relative Skill

Composition (RSC) index is the log of the ratio of low-skilled to skilled labor in the migrant relative to the resident population. Individual's controls are as in Table 3. The table reports linear model results.

Table 5 - Migration relative skill composition (RSC) and child labor (smallest sample)

\begin{tabular}{|c|c|c|c|c|c|c|c|c|c|c|}
\hline \multirow[b]{3}{*}{ RSC*HhH low-skill } & (1) & (2) & (3) & (4) & (5) & (6) & (7) & (8) & (9) & $(10)$ \\
\hline & \multicolumn{2}{|c|}{ Any work } & \multicolumn{2}{|c|}{ Market work } & \multicolumn{2}{|c|}{ Family business } & \multicolumn{2}{|c|}{ Chores } & \multicolumn{2}{|c|}{ School attendance } \\
\hline & $\begin{array}{l}-0.062 \\
(0.039)\end{array}$ & $\begin{array}{l}-0.060 \\
(0.047)\end{array}$ & $\begin{array}{c}-0.038^{* *} \\
(0.018)\end{array}$ & $\begin{array}{l}-0.037 * \\
(0.018)\end{array}$ & $\begin{array}{l}-0.034 * \\
(0.017)\end{array}$ & $\begin{array}{l}-0.033^{*} \\
(0.018)\end{array}$ & $\begin{array}{l}-0.029 * \\
(0.016)\end{array}$ & $\begin{array}{l}-0.029 * \\
(0.016)\end{array}$ & $\begin{array}{c}0.110 * * * \\
(0.032)\end{array}$ & $\begin{array}{c}0.108 * * * \\
(0.035)\end{array}$ \\
\hline $\begin{array}{l}\text { Remittances*HhH } \\
\text { low-skilled }\end{array}$ & & $\begin{array}{c}-0.002 * * \\
(0.001)\end{array}$ & & $\begin{array}{c}-0.001^{* *} \\
(0.000)\end{array}$ & & $\begin{array}{c}-0.001 * * * \\
(0.000)\end{array}$ & & $\begin{array}{l}-0.000 \\
(0.000)\end{array}$ & & $\begin{array}{l}-0.001 \\
(0.000)\end{array}$ \\
\hline HhH low-skilled & $\begin{array}{c}0.033^{* * *} \\
(0.009)\end{array}$ & $\begin{array}{c}0.040^{* * *} \\
(0.011)\end{array}$ & $\begin{array}{c}0.015^{* * *} \\
(0.005)\end{array}$ & $\begin{array}{c}0.019^{* * *} \\
(0.006)\end{array}$ & $\begin{array}{c}0.012^{* *} \\
(0.005)\end{array}$ & $\begin{array}{c}0.016 * * * \\
(0.005)\end{array}$ & $\begin{array}{c}0.012^{* *} \\
(0.005)\end{array}$ & $\begin{array}{l}0.012^{* *} \\
(0.005)\end{array}$ & $\begin{array}{c}-0.048^{* * *} \\
(0.008)\end{array}$ & $\begin{array}{c}-0.045^{* * *} \\
(0.010)\end{array}$ \\
\hline $\begin{array}{l}\text { Individual's controls } \\
\text { Country fixed }\end{array}$ & yes & yes & Yes & yes & yes & yes & yes & yes & yes & yes \\
\hline effects & yes & yes & Yes & yes & yes & yes & yes & yes & yes & yes \\
\hline Observations & 221,037 & 221,037 & 221,037 & 221,037 & 221,037 & 221,037 & 221,037 & 221,037 & 67,998 & 67,998 \\
\hline R-squared & 0.175 & 0.175 & 0.087 & 0.088 & 0.075 & 0.075 & 0.079 & 0.079 & 0.368 & 0.368 \\
\hline
\end{tabular}

Robust standard errors are reported in parentheses, clustered at the country level $* * * p<0.01, * * p<0.05, * 0<0.1$

Notes: Dependent variables are dichotomous indicators for working more than 28 hours in the last week. School attendance is a dichotomous variable referred to the current year. The sample includes children aged 5-14 in 28 countries (i.e. those for which remittances are available). The Relative Skill Composition (RSC) index is the log of the ratio of low-skilled to skilled labor in the migrant relative to the resident population.

Other controls are as in Table 3. The table reports linear model results. 
Table 6 - Lagged migration relative skill composition (RSC) and child labor (largest sample) - IV estimates

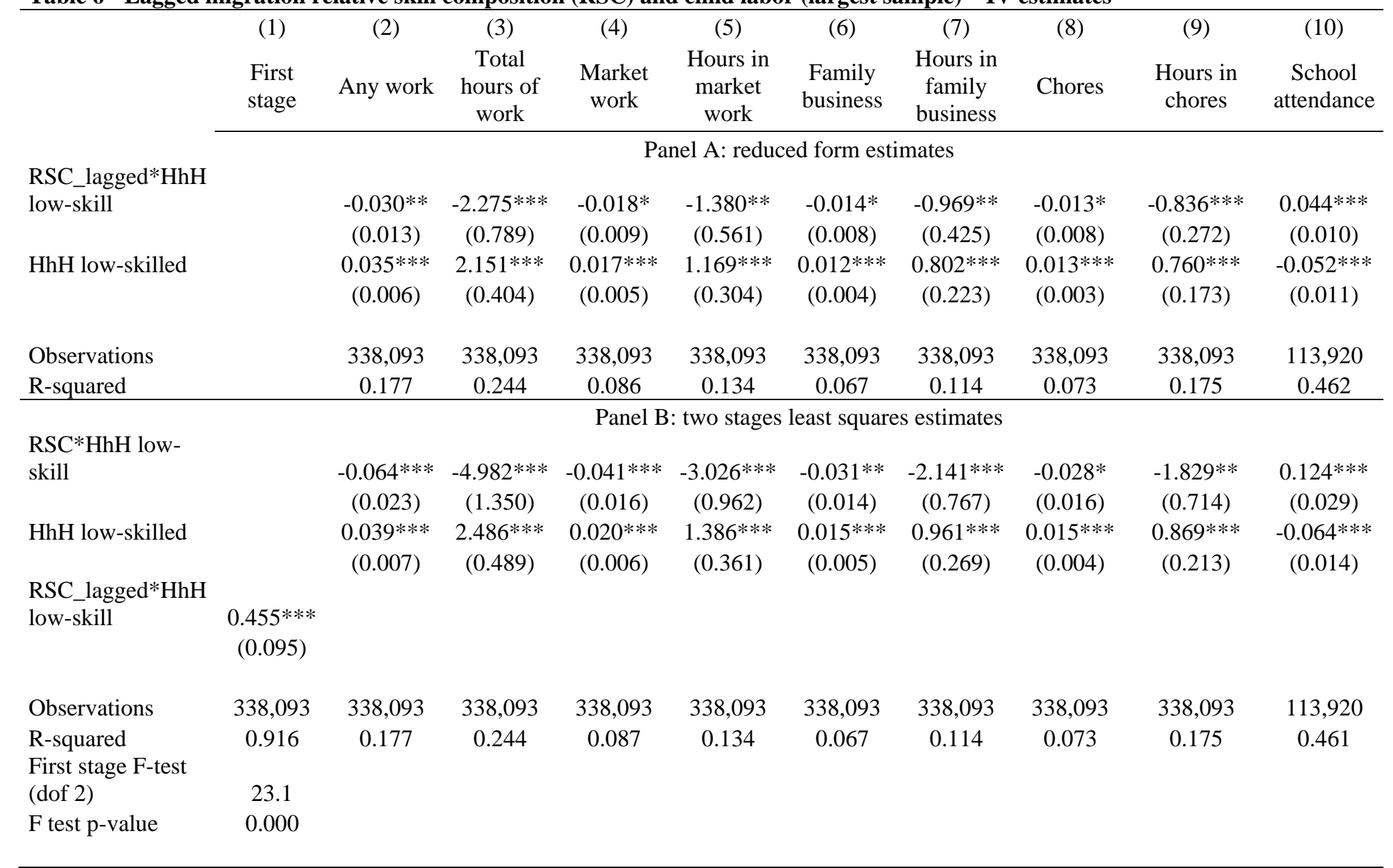

Robust standard errors are reported in parentheses, clustered at the country level. ${ }^{* * *} \mathrm{p}<0.01,{ }^{* *} \mathrm{p}<0.05,{ }^{*} \mathrm{p}<0.1$

Notes: Dependent variables are dichotomous indicators for working more than 28 hours and continuous indicators (i.e. hours). They are on a weekly basis. School attendance is a dichotomous variable referred to the current year. The sample includes children aged 5-14 in 38 countries.

The Relative Skill Composition (RSC) index is the log of the ratio of low-skilled to skilled labor in the lagged migrant relative to the resident population. Other controls are as in Table 3. The table reports linear model results. Panel A reports reduced form estimates, while Panel B reports two stages least squares estimates, including the first stage regression with the F-test for weak instruments. 
Table 7 - Child labor response to migration by child gender (largest sample)

\begin{tabular}{lcccccccccc}
\hline & $(1)$ & $\begin{array}{c}(2) \\
\text { Any work }\end{array}$ & $\begin{array}{c}\text { Total hours } \\
\text { of work }\end{array}$ & $\begin{array}{c}\text { Market } \\
\text { work }\end{array}$ & $\begin{array}{c}\text { Hours in } \\
\text { market work }\end{array}$ & $\begin{array}{c}\text { Family } \\
\text { business }\end{array}$ & $\begin{array}{c}\text { Hours in family } \\
\text { business }\end{array}$ & $\begin{array}{c}(7) \\
\text { Chores }\end{array}$ & $\begin{array}{c}(8) \\
\text { Hours in } \\
\text { chores }\end{array}$ & $\begin{array}{c}\text { School } \\
\text { attendance }\end{array}$ \\
\hline \multirow{2}{*}{$\begin{array}{c}\text { RSC*HhH low- } \\
\text { skill }\end{array}$} & $-0.054^{*}$ & $-4.205^{* *}$ & $-0.046^{* *}$ & $-2.813^{* *}$ & $-0.037^{* *}$ & $-2.198^{* *}$ & $-0.026^{*}$ & -0.992 & 0.067 \\
HhH low-skilled & $(0.028)$ & $(1.698)$ & $(0.020)$ & $(1.228)$ & $(0.016)$ & $(0.953)$ & $(0.014)$ & $(0.745)$ & $(0.041)$ \\
& $0.042^{* * *}$ & $2.527^{* * *}$ & $0.020^{* * *}$ & $1.300^{* * *}$ & $0.015^{* * *}$ & $1.010^{* * *}$ & $0.020^{* * *}$ & $1.010^{* * *}$ & $-0.053^{* * *}$ \\
& $(0.007)$ & $(0.499)$ & $(0.006)$ & $(0.397)$ & $(0.005)$ & $(0.298)$ & $(0.004)$ & $(0.244)$ & $(0.013)$
\end{tabular}

\begin{tabular}{lcccccccccc}
$\begin{array}{l}\text { Individual's } \\
\text { controls }\end{array}$ & yes & yes & yes & yes & yes & yes & yes & yes & yes \\
$\begin{array}{l}\text { Country fixed } \\
\text { effects }\end{array}$ & & & & & & & & & & \\
yes & yes & yes & yes & yes & yes & yes & yes & yes \\
Observations & 168,065 & 168,065 & 168,065 & 168,065 & 168,065 & 168,065 & 168,065 & 168,065 & 55,426 \\
R-squared & 0.185 & 0.258 & 0.086 & 0.138 & 0.065 & 0.118 & 0.088 & 0.184 & 0.481 \\
\hline & & & \multicolumn{9}{c}{ Panel B: male children } \\
RSC*HhH low- & $-0.059^{* *}$ & $-4.186^{* *}$ & $-0.037^{* *}$ & $-2.653^{* *}$ & $-0.028^{*}$ & $-1.597 *$ & $-0.037^{* *}$ & $-1.646^{* * *}$ & $0.092^{* * *}$ \\
skill & $(0.027)$ & $(1.549)$ & $(0.017)$ & $(1.084)$ & $(0.015)$ & $(0.836)$ & $(0.015)$ & $(0.599)$ & $(0.028)$ \\
HhH low-skilled & $0.034^{* * *}$ & $2.196^{* * *}$ & $0.020^{* * *}$ & $1.361^{* * *}$ & $0.014^{* * *}$ & $0.815^{* * *}$ & $0.011^{* * *}$ & $0.580^{* * *}$ & $-0.060^{* * *}$ \\
& $(0.007)$ & $(0.476)$ & $(0.006)$ & $(0.381)$ & $(0.005)$ & $(0.266)$ & $(0.004)$ & $(0.171)$ & $(0.011)$
\end{tabular}

Individual's

controls

Country fixed

effects yes yes yes

\begin{tabular}{lccccccccc} 
R-squared & 0.172 & 0.234 & 0.091 & 0.135 & 0.073 & 0.116 & 0.055 & 0.161 & 0.449 \\
\hline
\end{tabular}

Robust standard errors are reported in parentheses, clustered at the country level. ${ }^{* *} \mathrm{p}<0.01,{ }^{* *} \mathrm{p}<0.05,{ }^{*} \mathrm{p}<0.1$

Notes: Dependent variables are dichotomous indicators for working more than 28 hours and continuous indicators (i.e. hours). School attendance is a dichotomous variable referred to the current year. The sample includes children aged 5-14 in 38 countries. The Relative Skill Composition (RSC) index is the log of the ratio of low-skilled to skilled labor in the migrant relative to the resident population. Other controls are as in Table 3. The table reports linear model results. 
Table 8 - Child labor response to male and female emigration shock (largest sample)

\begin{tabular}{|c|c|c|c|c|c|c|c|c|c|}
\hline & Any work & $\begin{array}{c}(2) \\
\text { Total } \\
\text { hours of } \\
\text { work }\end{array}$ & $\begin{array}{c}(3) \\
\text { Market } \\
\text { work }\end{array}$ & $\begin{array}{c}(4) \\
\text { Hours in } \\
\text { market } \\
\text { work }\end{array}$ & $\begin{array}{l}\text { (5) } \\
\text { Family } \\
\text { business }\end{array}$ & $\begin{array}{c}\text { (6) } \\
\text { Hours in } \\
\text { family } \\
\text { business }\end{array}$ & Chores & $\begin{array}{l}\text { (8) } \\
\text { Hours in } \\
\text { chores }\end{array}$ & $\begin{array}{c}\text { (9) } \\
\text { School } \\
\text { attendance }\end{array}$ \\
\hline & \multicolumn{9}{|c|}{ Panel A: Male migration } \\
\hline $\begin{array}{l}\text { RSC_male*HhH } \\
\text { low-skill }\end{array}$ & $\begin{array}{l}-0.034^{*} \\
(0.019)\end{array}$ & $\begin{array}{c}-2.745^{* *} \\
(1.099)\end{array}$ & $\begin{array}{c}-0.031 * * \\
(0.014)\end{array}$ & $\begin{array}{c}-1.952 * * \\
(0.796)\end{array}$ & $\begin{array}{l}-0.023^{*} \\
(0.011)\end{array}$ & $\begin{array}{c}-1.204 * * \\
(0.577)\end{array}$ & $\begin{array}{c}-0.022^{*} \\
(0.011)\end{array}$ & $\begin{array}{c}-1.041^{* *} \\
(0.503)\end{array}$ & $\begin{array}{c}0.074 * * * \\
(0.019)\end{array}$ \\
\hline HhH low-skilled & $\begin{array}{c}0.036^{* * *} \\
(0.007)\end{array}$ & $\begin{array}{c}2.209 * * * \\
(0.436)\end{array}$ & $\begin{array}{c}0.020^{* * *} \\
(0.006)\end{array}$ & $\begin{array}{c}1.299 * * * \\
(0.366)\end{array}$ & $\begin{array}{c}0.014 * * * \\
(0.005)\end{array}$ & $\begin{array}{c}0.814^{* * * *} \\
(0.250)\end{array}$ & $\begin{array}{c}0.015^{* * * *} \\
(0.004)\end{array}$ & $\begin{array}{c}0.774^{* * * *} \\
(0.208)\end{array}$ & $\begin{array}{c}-0.064 * * * \\
(0.013)\end{array}$ \\
\hline $\begin{array}{l}\text { Individual's controls } \\
\text { Country fixed effects } \\
\text { Observations } \\
\text { R-squared }\end{array}$ & $\begin{array}{c}\text { yes } \\
\text { yes } \\
241,813 \\
0.181 \\
\end{array}$ & $\begin{array}{c}\text { yes } \\
\text { yes } \\
241,813 \\
0.249 \\
\end{array}$ & $\begin{array}{c}\text { yes } \\
\text { yes } \\
241,813 \\
0.091 \\
\end{array}$ & $\begin{array}{c}\text { yes } \\
\text { yes } \\
241,813 \\
0.137 \\
\end{array}$ & $\begin{array}{c}\text { yes } \\
\text { yes } \\
241,813 \\
0.071 \\
\end{array}$ & $\begin{array}{c}\text { yes } \\
\text { yes } \\
241,813 \\
0.117 \\
\end{array}$ & $\begin{array}{c}\text { yes } \\
\text { yes } \\
241,813 \\
0.077 \\
\end{array}$ & $\begin{array}{c}\text { yes } \\
\text { yes } \\
241,813 \\
0.184 \\
\end{array}$ & $\begin{array}{c}\text { yes } \\
\text { yes } \\
87,130 \\
0.447 \\
\end{array}$ \\
\hline R-squared & \multicolumn{9}{|c|}{ Panel B: Female migration } \\
\hline $\begin{array}{l}\text { RSC_female*Mother } \\
\text { low skilled }\end{array}$ & $\begin{array}{l}-0.052 \\
(0.052)\end{array}$ & $\begin{array}{l}-4.881 \\
(2.963)\end{array}$ & $\begin{array}{c}-0.069 * * \\
(0.027)\end{array}$ & $\begin{array}{l}-3.042^{*} \\
(1.648)\end{array}$ & $\begin{array}{c}-0.055^{* *} \\
(0.023)\end{array}$ & $\begin{array}{l}-2.202 \\
(1.485)\end{array}$ & $\begin{array}{l}-0.036^{*} \\
(0.018)\end{array}$ & $\begin{array}{c}-1.805^{* *} \\
(0.880)\end{array}$ & $\begin{array}{c}0.121^{* *} \\
(0.059)\end{array}$ \\
\hline Mother low skilled & $\begin{array}{l}0.025^{*} \\
(0.013)\end{array}$ & $\begin{array}{l}1.695^{* *} \\
(0.786)\end{array}$ & $\begin{array}{l}0.017 * * \\
(0.007)\end{array}$ & $\begin{array}{l}0.901^{*} \\
(0.462)\end{array}$ & $\begin{array}{l}0.012 * \\
(0.006)\end{array}$ & $\begin{array}{c}0.576 \\
(0.407)\end{array}$ & $\begin{array}{l}0.010^{*} \\
(0.005)\end{array}$ & $\begin{array}{c}0.606 * * \\
(0.263)\end{array}$ & $\begin{array}{c}-0.068 * * * \\
(0.018)\end{array}$ \\
\hline Individual's controls & yes & yes & yes & yes & yes & yes & yes & yes & yes \\
\hline Country fixed effects & yes & yes & yes & yes & yes & yes & yes & yes & yes \\
\hline Observations & 241,813 & 241,813 & 241,813 & 241,813 & 241,813 & 241,813 & 241,813 & 241,813 & 87,130 \\
\hline R-squared & 0.180 & 0.248 & 0.090 & 0.136 & 0.071 & 0.116 & 0.077 & 0.184 & 0.446 \\
\hline $\begin{array}{l}\text { Robust standard error } \\
\text { Notes: Dependent var } \\
\text { School attendance is a } \\
\text { that live with the mot } \\
\text { low-skilled males(fen } \\
\text { RSC on females is int } \\
\text { child gender, urban/r }\end{array}$ & $\begin{array}{l}\text { re reporte } \\
\text { bles are d } \\
\text { lichotomo } \\
\mathrm{r} \text { and have } \\
\text { les) to skil } \\
\text { acted with }\end{array}$ & $\begin{array}{l}\text { in parenth } \\
\text { chotomous } \\
\text { s variable } r \\
\text { a male hou } \\
\text { led male(fe } \\
\text { the dummy }\end{array}$ & ale) labor & $\begin{array}{l}\text { at the } \mathrm{c} \\
\text { workin }\end{array}$ & $\begin{array}{l}\text { try level. } \\
\text { tore than } \\
\text { r. The sar } \\
\text { e Skill Co }\end{array}$ & $* \mathrm{p}<0.01$ & $* \mathrm{p}<0.05$ & $\begin{array}{l}\mathrm{p}<0.1 \\
\text { indicator }\end{array}$ & $\begin{array}{l}\text { i.e. hours). } \\
8 \text { countries } \\
\text { the ratio of } \\
\text { anel B the }\end{array}$ \\
\hline
\end{tabular}


Figure 1 - Scatter plot of the correlation between the RSC index and the relative unskilled wages

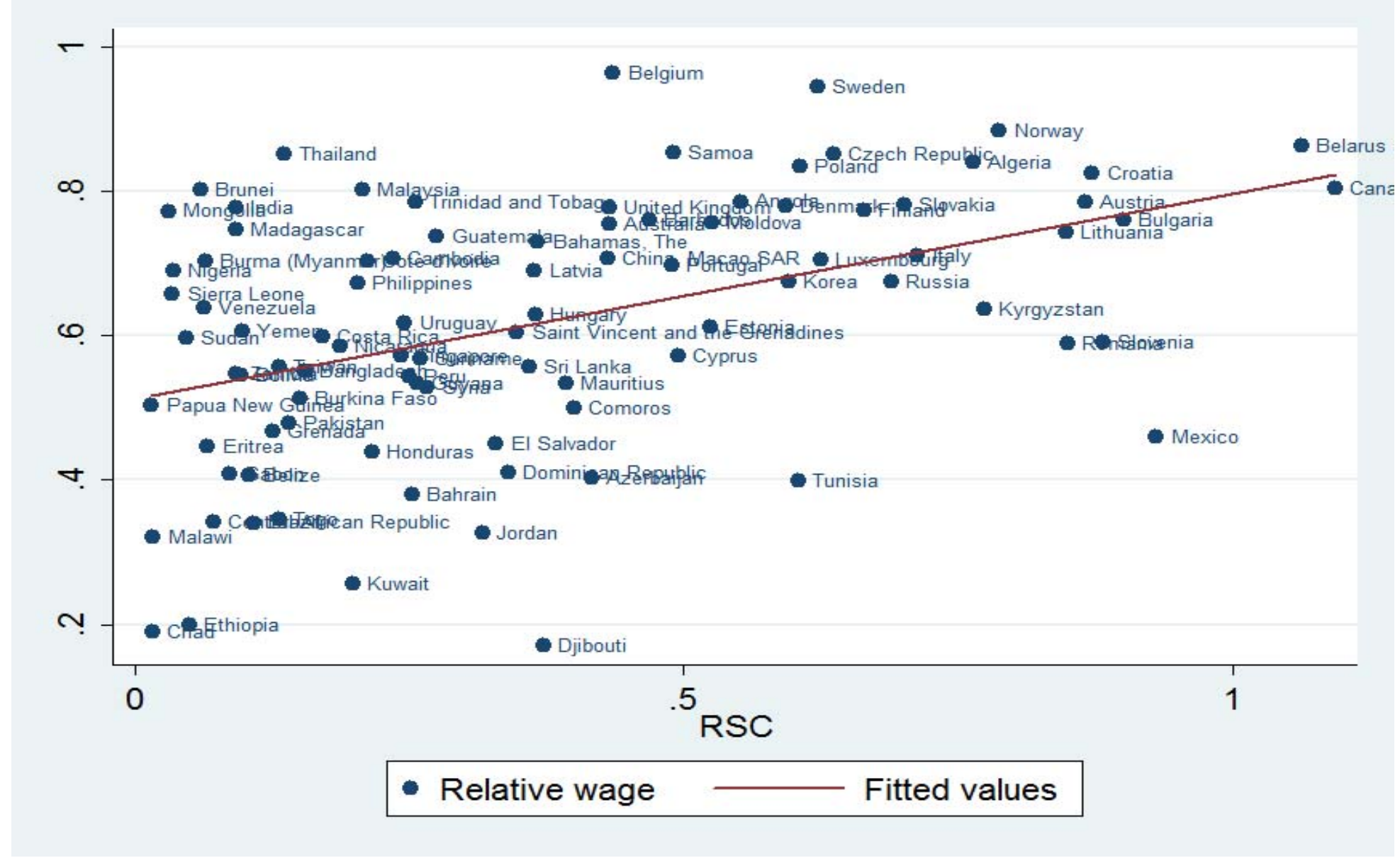

Source: Data are from Docquier et al. (2007) and Oostendorp (2012)

Note: The database used to construct this figure contains wage data by skill (occupations) and relative skill composition (RSC) of emigrant to resident workforce for a set of 91 countries in 2000. The RSC index is the log of the ratio of low-skilled to skilled workers in the migran relative to the resident population. The wage data are derived from the International Labour Organization (ILO) October Inquiry database by calibrating the data into a normalized wage rate for each occupation. For a description of the data see Oostendorp (2012). 
Figure 2 - Scatter plot of the correlation between country-level incidence of child labor and the RSC index

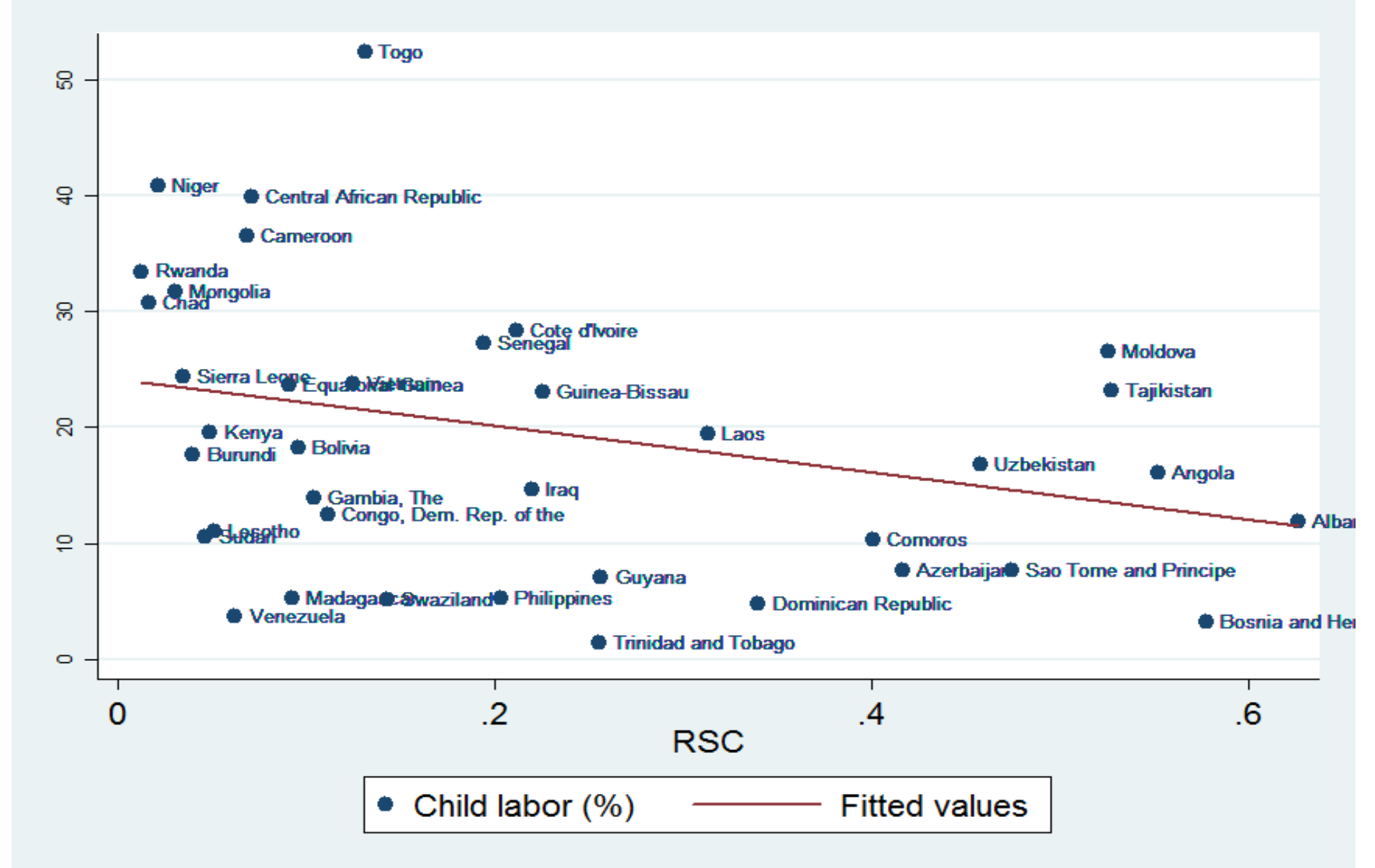

Source: Data are from MICSII-UNICEF (2000) and Docquier et al. (2007).

Note: The database used to construct this figure contains child labor data relative skill composition (RSC) of emigrant to resident workforce for a set of 38 countries in 2000. The RSC index is the log of the ratio of low-skilled to skilled workers in the migrant relative to the resident population. The child labor rate is the country-level number of working children in the age 5-14 over the total child population in 2000. 